NBER WORKING PAPER SERIES

\title{
DELIBERATE SURRENDER? THE IMPACT OF INTERWAR INDIAN PROTECTION
}

\author{
Vellore Arthi \\ Markus Lampe \\ Ashwin R Nair \\ Kevin Hjortshøj O'Rourke \\ Working Paper 27178 \\ http://www.nber.org/papers/w27178 \\ NATIONAL BUREAU OF ECONOMIC RESEARCH \\ 1050 Massachusetts Avenue \\ Cambridge, MA 02138 \\ May 2020, Revised December 2022
}

Previously circulated as "The Impact of Interwar Protection: Evidence from India." O'Rourke gratefully acknowledges the financial support of the ERC, under the European Union's Seventh Framework Programme (FP7/2007-2013), ERC grant agreement no. 249546; the Oxford History Faculty's Sanderson Fund; and the John Fell OUP Research Fund. We are extremely grateful to Emma Mathieson and the rest of the staff of the Bodleian Library and Oxford's Oriental Institute Library for their generous assistance in locating material. Aileen Mooney's help was invaluable in getting financial support for the project and we thank her most sincerely. We are also very grateful to Bob Allen, Mike Bordo, Luis Catao, Mary Cox, Ron Davies, Alan de Bromhead, Alan Fernihough, James Foreman-Peck, Paulo Guimarães, Bishnu Gupta, Stefanie Haller, Jean Imbs, Ignacio Marra, Chris Meissner, Chris Minns, Ferdinand Rauch, Tirthankar Roy, Alan Taylor, and Susan Wolcott for answering our questions, sharing data, providing comments and suggestions, and helping us in a variety of other ways. A special word of thanks is due to Alex Green, Thea Don-Siemion, and Brian Varian for finding data for us in the LSE library. We benefitted from some great comments when presenting this work at Cardiff University, the University of Warwick, the University of York, McMaster University, Martin Luther University HalleWittenberg, the University of Groningen, Wageningen University, New York University, Zayed University, the 2019 Economic History Society annual conference in Belfast, and the Dublin Trade Group, and thank all concerned. The usual disclaimer applies. The views expressed herein are those of the authors and do not necessarily reflect the views of the National Bureau of Economic Research.

NBER working papers are circulated for discussion and comment purposes. They have not been peer-reviewed or been subject to the review by the NBER Board of Directors that accompanies official NBER publications.

(C) 2020 by Vellore Arthi, Markus Lampe, Ashwin R Nair, and Kevin Hjortshøj O'Rourke. All rights reserved. Short sections of text, not to exceed two paragraphs, may be quoted without explicit permission provided that full credit, including $\left({ }^{\circ}\right.$ notice, is given to the source. 
Deliberate Surrender? The Impact of Interwar Indian Protection

Vellore Arthi, Markus Lampe, Ashwin R Nair, and Kevin Hjortshøj O'Rourke

NBER Working Paper No. 27178

May 2020, Revised December 2022

JEL No. F13,F14,N75

\begin{abstract}
$\underline{\text { ABSTRACT }}$
What is the role of trade policy in promoting intra-Empire trade? We address the question in the context of interwar India, whose trade policies have been accused of harming British export interests. We quantify the impact of trade policy on the value and composition of Indian imports, using novel disaggregated data on both trade policies and imports for 114 commodity categories coming from 42 countries. We find that even though Indian protection lowered total imports, it substantially boosted imports from the UK. Despite the rising tariff barriers facing British exporters, trade diversion from other countries ensured that Indian trade policy benefited them overall.

Vellore Arthi

Department of Economics

3151 Social Sciences Plaza

University of California, Irvine

Ashwin R Nair

Irvine, CA 92697

and NBER

varthi@uci.edu

IFMR Graduate School of Business

Krea University

ashwin.nair@ifmr.ac.in

Kevin Hjortshøj O'Rourke

NYU Abu Dhabi, Saadiyat Campus

Markus Lampe

Social Science (A5), 1193

P.O. Box 129188

Institute for Economic and Social History

Abu Dhabi

Vienna University of Economics and Business

United Arab Emirates

Welthandelsplatz 1

and NBER

Geb. D4, 3. Stock

kevin.orourke@nyu.edu

$1020 \mathrm{Wien} /$ Vienna

Austria

markus.lampe@wu.ac.at
\end{abstract}




\section{Introduction}

How does imperialism influence international trade? In recent years, researchers have documented a positive impact of empire on trade flows, which declines after independence but still persists (albeit to a much lesser extent) decades later (Head, Mayer and Ries, 2010). Mitchener and Weidenmier (2008) suggest that the late 19th century British Empire boosted intra-imperial trade flows via preferential trade policy and lower transaction costs. Head, Mayer and Ries (2010, p. 12) prefer an alternative mechanism: "trade-promoting capital embodied in institutions and networks of individuals with knowledge of trading opportunities". This is consistent with the time pattern they observe: the impact of empire erodes steadily, rather than falling abruptly as one might expect if newly independent colonies suddenly terminated preferential trade relationships. ${ }^{1}$

This paper studies the impact of colonial trade policy, focussing on the most important colony of all, namely India. It explores the impact of interwar Indian trade policy on imports from Britain, and concludes that this was large and positive. This may seem counter-intuitive: whereas in the late nineteenth century Britain had been a free trader, imposing liberal trade policies on its colonies, by the 1920s the Indian colonial government had won the right to impose tariffs, and did so on cotton textiles and other manufactured goods that had traditionally been imported from Britain. Dewey (1978, p. 36) states that higher Indian tariffs "ejected Lancashire from its largest export market". ${ }^{2}$ If this was, as Dewey claimed, the "deliberate surrender of the largest export market in the world for a staple British manufacture", it would be a striking example of a colonial power permitting policies that damaged its own export interests.

Not everyone agrees with Dewey's assessment: Chaudhuri (1983, p. 869) suggests that Imperial Preference may have boosted Britain's share of Indian imports, while Rothermund (1988, p. 110) argues that quotas on Japanese cotton exports to India enabled the British "to recover a great deal of the ground that they had lost both to Indian and to Japanese competition in previous years". Empirical evidence is required to discriminate between such assertions, but while there is an abundant historical literature on the politics of Indian interwar trade policy, there has been much less work on the consequences of

\footnotetext{
${ }^{1}$ Eichengreen and Irwin (1995, p. 22) agree. They find that British Empire membership increased bilateral trade during the 1920s, before the switch to Imperial Preferences of the 1930 s, and conclude that this was due to "commercial and financial linkages between countries forged over many years."

${ }^{2}$ For similar views see Drummond (1972, pp. 123-4) and Sandberg (1974).
} 
that policy. ${ }^{3}$ The only quantitative study of the impact on trade flows of Indian interwar protection that we are aware of is Wolcott (1991), who estimates partial equilibrium import demand curves for British cotton textiles and concludes that $82 \%$ of the decline in the Indian demand for British cotton textiles was due to the increase in the tariff from 11 to $25 \%$ : Indian protection hit British exports severely.

In this paper we extend the analysis in several ways. First, we look at the impact of Indian protection not just on imports of cotton textiles, but on imports more generally. We do so using a newly created dataset of imports into British India of 114 consistently-defined commodities from 42 countries over the 15 years 1923-4 to 1937-8. ${ }^{4}$ Generating these data required typing information on imports of 202 sub-categories of goods from 63 countries or sub-regions. Second, we look at imports not just from the UK but from the 41 other countries in our dataset, and we take account of Indian trade policies affecting those countries also. A partial equilibrium assessment of the impact of Indian tariffs on British exports alone is bound to conclude that it was negative; our model allowing for trade with other countries, a richer range of substitution possibilities, and trade diversion reaches the opposite conclusion.

Third, whereas previous papers have estimated the impact of interwar trade policy using dummy variables or other aggregate measures of protection, we use data on trade and trade policy that is disaggregated by commodity and country. This allows for a far more precise estimate of the impact of protection. Fourth, we estimate interwar Indian trade elasticities using tariff data, responding to the call of Goldberg and Pavcnik (2016, p. 181) for "careful empirical work that exploits trade policy variation in order to identify the trade elasticity/ies". And fifth, we embed our elasticities within a small open economy model with an extremely simple supply side, but a very detailed demand side allowing for substitution between varieties of the same goods coming from different countries, substitution between different goods, and substitution between imports in general and domestically produced goods.

We find that Indian protection depressed overall imports (our mean estimate is that protection lowered imports by around 10\%), but substantially boosted imports from the United Kingdom. Our mean estimates suggest that total British exports to India were increased by over $20 \%$, and UK cotton cloth exports to

\footnotetext{
${ }^{3}$ For recent contributions see Stubbings (2019) and Casler and Gaikwad (2019).

${ }^{4}$ The data will be made available to researchers at https://cepr.org/research/data-setitems.
} 
the country by almost $90 \%$ : these impacts were equivalent to around $2 \%$ of aggregate UK exports, and over $15 \%$ of UK cotton cloth exports, to all destinations. Permitting India to set its own trade policy did not imply a deliberate surrender of British export markets.

Our work contributes most obviously to the afore-mentioned literature on trade and empire, as well as to the rapidly growing quantitative literature on Indian economic history (for a recent survey, see Chaudhary et al. (2015)). Our results also speak to a small but growing literature quantifying the impact of interwar tariffs and quotas. Surprisingly, despite their outsize reputation, existing empirical work quantifying their effects has typically found smaller effects than might have been expected, given the prominent role assigned to protectionism in many historical accounts of the Great Depression. ${ }^{5}$ Furthermore, most empirical work on the subject has focussed on rich countries, particularly the United Kingdom and United States, whereas we quantify the impact of interwar trade policy in a developing country. The article also contributes to a recent literature using tariffs to estimate trade elasticities (e.g. Caliendo and Parro (2015), Fajgelbaum et al. (2020), Imbs and Mejean (2017), and Fontagné, Guimbard and Orefice (2022)), but does so using evidence from a very different historical context. Finally, we contribute to a recent empirical literature analysing protectionism and trade disruptions (e.g. Amiti, Redding and Weinstein, 2019; Conesa et al., 2021; McGrattan and Waddle, 2020; Steinberg, 2019, 2020)

We begin with a brief description of Indian trade policy during the period. Section 3 outlines our theoretical framework and introduces the key elasticities which matter for our results. Section 4 describes the data which are used to estimate those elasticities in Section 5. Section 6 derives the main results of our paper and Section 7 concludes.

\footnotetext{
${ }^{5}$ Irwin (2012) provides an excellent survey. To take one example, Irwin (1998) finds that the bulk of the 1929-33 US trade collapse was due more to the GDP collapse of the period than to an increase in trade frictions. To take another, as already noted Eichengreen and Irwin (1995) find little evidence that imperial and regional trade blocs distorted the geographical pattern of trade during the 1930s: the countries involved had already traded disproportionately with each other in the 1920s, prior to the introduction of discriminatory trade policies. Madsen (2001) and Kitson and Solomou (1990) provide dissenting voices. See also, inter alia, de Bromhead et al. (2019), Estevadeordal, Frantz and Taylor (2003), Gowa and Hicks (2013), and Wolf and Ritschl (2011).
} 


\section{Indian trade policy ${ }^{6}$}

Indian import tariffs had traditionally been low, reflecting the country's colonial status and the liberal inclinations of the British imperial power. Land, opium, and salt provided the bulk of the Indian government's revenues in the nineteenth century: customs duties only accounted for $10 \%$ of government revenue in 186061 , and just $5 \%$ ten years later (Kumar, 1983, p. 916). On the eve of World War 1 India was still virtually a free-trading country, and such tariffs as were levied were designed to raise revenue rather than to protect domestic industries.

The war was an important turning point. The war effort required revenue, and Indian tariffs were accordingly increased: customs duties accounted for $20 \%$ of Indian government revenue during 1916-20 (Mukherjee, 2001, pp. 731-2). The war also "produced a landslip in official attitudes to protection" (Dewey, 1978, p. 45). Total war highlighted the desirability of developing Indian heavy industry, while the belief in laisser faire was shaken. Even more importantly, perhaps, Indian nationalist demands were strengthened by the country's contribution to the war effort. In August 1917 the Secretary of State for India, Edwin Montagu, stated that the UK favoured "the progressive realization of responsible government in India as an integral part of the Empire."

In 1919, a British Joint Select Committe stated that "Nothing is more likely to endanger the good relations between India and Great Britain than a belief that India's fiscal policy is dictated from Whitehall in the interests of the trade of Great Britain. That such a belief exists at the moment there can be no doubt... Whatever be the right fiscal policy for India, for the needs of her consumers as well as for her manufacturers, it is quite clear that she should have the same liberty to consider her interests as Great Britain, Australia, New Zealand, Canada and South Africa." It thus proposed (and the government subsequently agreed) that the British government "should as far as possible avoid interference on this subject when the Government of India and its Legislature are in agreement" (U.K. Parliamentary Papers, 1919, p. 11).

This recommendation, accepted by the British government in 1921, that Britain acknowledge India's right to "fiscal autonomy" took the form of a "convention" rather than a statute, since the latter would have limited "the ultimate power of Parliament to control the administration of India" and "the power of veto which rests in the Crown". Indian historians have pointed out that the Government of India was supposed to consult the British government before

\footnotetext{
${ }^{6} \mathrm{~A}$ lengthier account is provided in Arthi et al. (2020).
} 
tabling fiscal policy proposals, and have argued that the British government de facto retained significant control over Indian trade policy (Mukherjee, 2001, pp. 734-5). Yet the succeeding two decades saw the gradual development of far more interventionist trade policies on the sub-continent.

In 1922 the Indian Fiscal Commission recommended protection for Indian industries on classic infant industry grounds (U.K. Parliamentary Papers, 1922 Sess II). ${ }^{7}$ Protection was to be resorted to "with discrimination", since indiscriminate protection "would protect industries unsuitable as well as suitable, and would impose on the consumer a burden in many cases wholly gratuitous" (p. 49). ${ }^{8}$ In 1923 the Indian government accepted this recommendation, and a Tariff Board was set up to implement it.

The new Tariff Board's first task was to consider the case for protection of the iron and steel industry. In June 1924 tariffs were introduced ranging from 15 to $25 \%$ ad valorem. ${ }^{9}$ In 1927 protection for the industry was extended for a further 7 years, and importantly the duties were now "differential", which is to say that they were in many cases lower for goods "of British manufacture". This legislation marked a break with the past: previous attempts to introduce Imperial Preferences of any kind had fallen foul of Indian nationalist opinion (which objected in this instance also, albeit unsuccessfully).

Protection for the Indian cotton industry also increased over time in response to worsening market conditions and concerns about unfair competition (due to inferior labour conditions) from East Asia. ${ }^{10}$ In April 1930 duties on British piece goods were increased to $15 \%$, with duties on foreign piece goods being raised to $20 \%{ }^{11}$ By the end of September 1931 these duties had been raised to $25 \%$ and $31 \frac{1}{4} \%$ respectively. ${ }^{12}$

In 1932 an Indian delegation attended the Imperial Economic Conference

\footnotetext{
${ }^{7}$ That is to say, Indian industries concerned would have to possess "natural advantages", require protection to be able to develop in the first place, and would eventually be competitive in world markets.

${ }^{8}$ Somewhat confusingly, therefore, the proposed policy was described by contemporaries as one of "discriminatory protection". Notably, 5 Indian members of the 11-member Commission argued for an unqualified commitment to protection (U.K. Parliamentary Papers, 1922 Sess II, pp. 175-212). Roy (2017) provides a sympathetic account of the policy of discriminatory protection.

${ }^{9}$ Several specific tariffs were also introduced.

${ }^{10}$ An excellent and concise account is given in Indian Tariff Board (1932, pp. 1-8), on which we largely draw.

${ }^{11}$ The legislation also specificied a minimum specific tariff of $3 \frac{1}{2}$ annas per pound on all imported plain grey piece goods, no matter what the origin, which was non-discriminatory enough to get the measure passed by an Indian Legislature hostile to Imperial Preference (Act XVII of 1930).

${ }^{12}$ Indian Finance (Supplementary and Extending) Act, 1931.
} 
in Ottawa alongside the UK and the Dominions, although it did so somewhat reluctantly. The British government hoped to deepen imperial economic unity, arguing in favour of greater imperial preferences and non-discrimination within the Empire. India and the UK struck a trade deal at Ottawa, granting tariff preferences in the Indian market to a large range of UK exports. These margins were generally $10 \%$ ad valorem, although in some cases (notably motor cars) the margin was $7 \frac{1}{2} \%$. The agreement did not prevent India from raising tariffs in the future so long as these preference margins were maintained (U.K. Parliamentary Papers, 1931-32; Drummond, 1972, p. 131). India also agreed to extend to Britain's colonies any preferences granted to the UK (subject to this being reciprocated by the colonies), and extended further preferences to the colonies on a range of specified goods. While the agreement was denounced by India in 1936, it remained in force until a new agreement was negotiated in 1939 (Meyer, 1948, pp. 116-7)

In December 1931 Japan quit the gold standard and the yen started to depreciate. On August 30, 1932 the Indian duty on all non-British cottons was increased from $31 \frac{1}{4}$ to $50 \%$ (the Indo-Japanese trade treaty of 1904, which had granted most-favoured-nation status to Japan, made it impossible to single out Japanese goods for special attention). ${ }^{13}$ In April 1933 India gave Japan six months notice of its intention to denounce the 1904 treaty, which would allow it to discriminate against Japanese imports; later in the same month the Indian Governor General was given the power to impose safeguard duties. On the 7th of June the tariff on non-British cotton goods was increased to $75 \%$.

Japan reacted to the increased tariff on non-British goods, in part by boycotting Indian raw cotton, but also by opening trade negotiations with India (Drummond, 1972, pp. 132-4; Rothermund, 1988, pp. 109-10; Chatterji, 1992, pp. 378-80). The outcome was a trade agreement which came into effect on January 8, 1934. This lowered the Indian duty on foreign piece goods to $50 \%$, in exchange for restrictions on Japanese exports of piece goods to India linked to Japanese imports of Indian raw cotton (Chatterji, 1992, p. 395).

The Tariff Board granted substantial protection to a further nine industries during this period. ${ }^{14}$ Figure 1 plots the unweighted average tariff imposed on

\footnotetext{
${ }^{13}$ Not unreasonably, the Japanese protested against the fact that tariffs on British goods were not being increased. This was dismissed by the British who took the view that preferences in India on British goods were not inconsistent with the UK's treaty obligations to Japan, presumably since British goods were not of "foreign origin" (Chatterji, 1992, p. 378).

${ }^{14}$ These were sugar, paper, matches, salt, heavy chemicals, plywood and tea-chests, sericulture, magnesium chloride, and gold thread. Rice and wheat were also singled out for protection (Tomlinson, 1979, pp. 61-2).
} 
Figure 1: Average Indian tariffs, 1923-4 to 1937-8

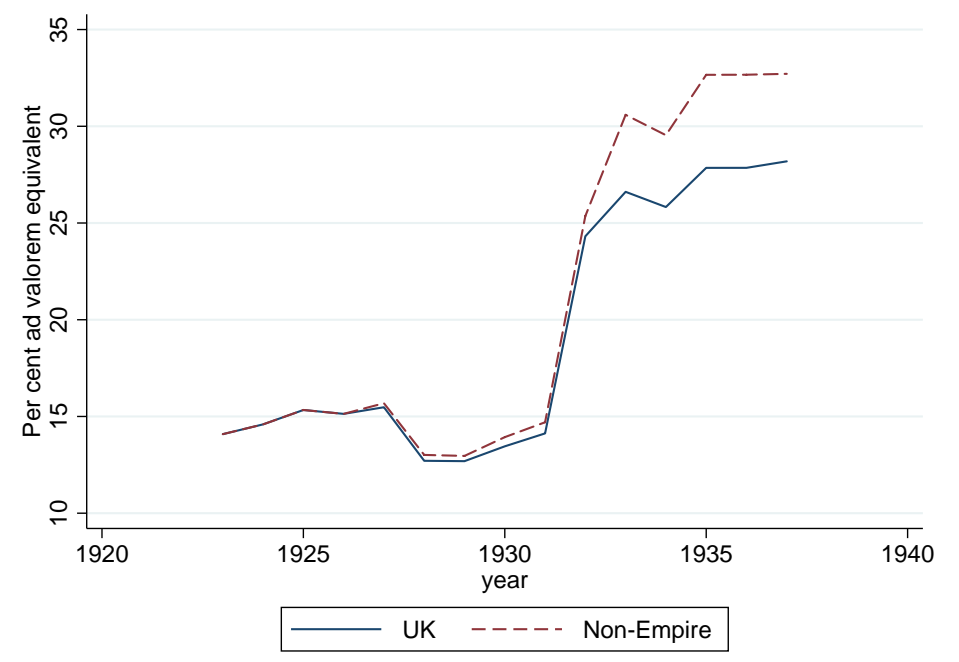

Note: this graph plots the unweighted average tariff imposed on goods imported into India from the UK, and from countries outside the British Empire.

Source: see Section 4.2 .

goods coming from the UK, and from countries outside the British Empire, over the period. It shows that the big increase in protection occurred in 1932, with average tariffs increasing from roughly 15 to $25 \%$, and that the gap between tariffs on British and "foreign" goods started widening in the subsequent year. What was the impact of these trends on the overall value and composition of Indian imports?

\section{Theoretical framework}

As the previous section has made clear, Indian trade policy became increasingly protectionist, and also more complicated, over the course of the 1920s and 1930s. Tariffs were increased on a wide range of goods, and they were raised more on imports from "foreign" countries than on British imports. Higher tariffs lowered imports, and a partial equilibrium analysis will necessarily conclude that they lowered UK exports to India. But tariffs which discriminated in favour of UK goods may have induced substitution towards British imports, potentially giving British exporters a larger share of a shrinking pie. What was the net effect of these countervailing forces? 
Figure 2: Nested utility function

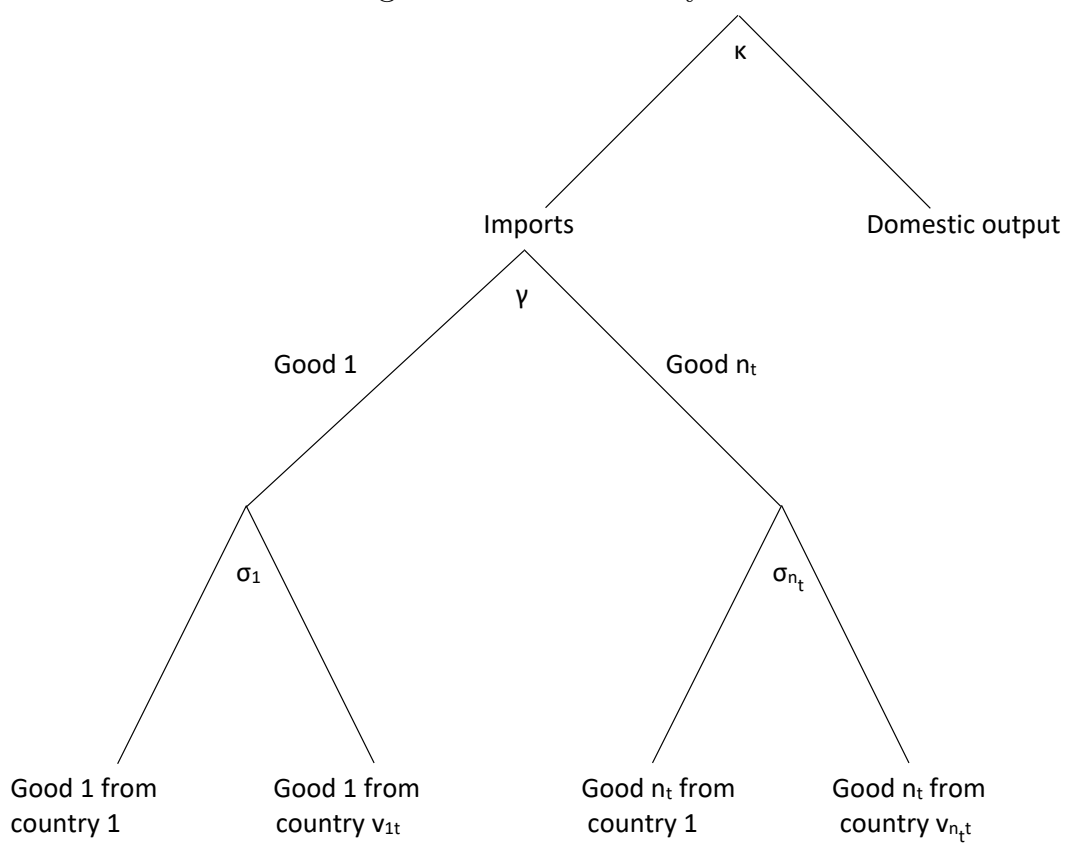

Note: this figure represents the nested utility function of the representative consumer. Each nest is CES, with the relevant elasticities being denoted by $\kappa, \gamma$, and $\sigma_{i}$. The number of goods imported in year $t$ is denoted by $n_{t}$ : it can vary over time since not all of our 114 goods are imported in every year. The number of national varieties of good $i$ imported in year $t$ is denoted by $v_{i t}$. In general this number is less than 42 , since not all countries export a paticular good to India in a particular year.

In order to answer this question we need a model of the Indian economy: ideally one with many goods originating in many countries being imported, and with corresponding domestic sectors producing these goods in India. We have data on Indian imports of 114 goods from 42 countries, which will be described in Section 4, but we lack Indian production data at the same level of disaggregation. We therefore construct, for each year $t$ from 1923 to 1937, a small open economy model with exogenous world prices of traded goods (inclusive of transport costs) and a very simple supply side, but with a much richer demand side based on Broda and Weinstein (2006), whose notation we largely use. ${ }^{15}$

The model's supply side is of necessity very sparse, and resembles that used by Anderson and Neary (1996): a single factor of production (which we can think

\footnotetext{
${ }^{15}$ Formally we thus construct 15 models, one for each year, calibrated to the data of the year in question. The models are similar in structure to those used by de Bromhead et al. (2019)
} 
of as GDP) is transformed into an export good $X_{t}$ and a domestically-consumed good $D_{t}$, via a constant elasticity of transformation (CET) production function (with the elasticity of transformation equal to $\eta$ ):

$$
G D P_{t}=\left(\theta D_{t}^{(1+\eta) / \eta}+(1-\theta) X_{t}^{(1+\eta) / \eta}\right)^{\eta /(1+\eta)}
$$

We let $X_{t}$ be the numéraire good. Producers maximize $X_{t}+p_{D_{t}} D_{t}$ subject to (1).

A single representative agent is endowed with all the GDP, and also earns any tariff revenues and quota rents. They maximize a nested CES utility function, represented in Figure 2, subject to the usual budget constraint. At the top level they choose between the domestically produced good $D_{t}$ and an aggregate import good $I_{t}$, with the elasticity of substitution between these two goods being denoted by $\kappa$ :

$$
U_{t}=\left(\alpha D_{t}^{(\kappa-1) / \kappa}+(1-\alpha) I_{t}^{(\kappa-1) / \kappa}\right)^{\kappa /(\kappa-1)}
$$

At the second level the aggregate import good $I_{t}$ is a CES composite of up to 114 imported goods $g \in G_{t}$ where $G_{t}$ is the set of all goods imported in period $t$. The elasticity of substitution between goods is denoted by $\gamma$, while $M_{g t}$ represents total imports of good $g$ in year $t$ :

$$
I_{t}=\left(\sum_{g \in G_{t}} \beta_{g t} M_{g t}^{(\gamma-1) / \gamma}\right)^{\gamma /(\gamma-1)}
$$

Finally, at the third level each of the imported goods $M_{g t}$ is an Armington aggregate of up to 42 varieties, with each variety of a good coming from a particular source country. The Armington elasticity of substitution betwen the different national varieties of good $g$ is denoted by $\sigma_{g}$; in the equation below $m_{\text {gct }}$ represents imports of good $g$ from country $c$ in year $t$, while $I_{g t} \subset C$ is the subset of all countries $C$ supplying good $g$ to India in year $t$ :

$$
M_{g t}=\left(\sum_{c \in I_{g t}} \delta_{g c t} m_{g c t}^{\left(\sigma_{g}-1\right) / \sigma_{g}}\right)^{\sigma_{g} /\left(\sigma_{g}-1\right)}
$$

The exogenous world prices of the traded goods $g$, inclusive of transport costs, vary by country $c$ and are denoted by $p_{g c t}^{W}$. Domestic prices $p_{g c t}^{D}$ are given by 


$$
p_{g c t}^{D}=\tau_{g c t} p_{g c t}^{W}
$$

where $\left(\tau_{g c t}-1\right)$ is the ad valorem equivalent percentage markup of domestic over world prices due to tariff and non-tariff barriers to trade. There was only one relevant non-tariff barrier to trade during our period, the quota affecting Japanese exports of cotton piece goods to India. The markup is thus given by

$$
\tau_{g c t}=\left(1+t_{g c t}\right) \times q^{v_{g c t}}
$$

where $t_{g c t}$ is the ad valorem tariff on imports of good $g$ from country $c$ in year $t$, and $q-1$ is the ad valorem tariff equivalent to the quota. $v_{g c t}$ is a dummy variable that is equal to one if imports of good $g$ from country $c$ were subject to the quota in year $t$, and zero otherwise.

The export good is sold to provide the foreign exchange used to buy imports (we assume that trade is balanced, which is another way of saying that the representative agent's income, inclusive of tariff revenues and quota rents, is equal to their expenditure on all goods, valued at domestic prices). To keep the analysis simple, and in line with the evidence provided in Section 4.1, we assume that the extensive margin of trade is fixed (i.e. that $I_{g t}$ and $G_{t}$ are fixed $\forall g, t)$.

It is convenient to define units so that all domestic prices are equal to one in the initial benchmark equilibrium in each year. Domestic prices of imported goods can then be exogenously changed in counterfactual scenarios, as tariffs and quotas are varied. Changes in these domestic prices $p_{g c t}^{D}$ imply changes in the prices of the 114 import goods, $M_{g t}$, and of the aggregate import good $I_{t}$. As these vary, the representative agent adjusts their consumption of all goods, including the domestic good $D_{t}$. Production therefore also adjusts, with the price of the domestic good, $p_{D_{t}}$, varying so as to ensure that production of the domestic good $D_{t}$ is equal to demand. We solve the model numerically using MPSGE (Rutherford, 1999).

When protection increases, the main determinants of the impact on the total value of imports will be the ease with which the consumer can substitute towards the domestically produced good, and the ease with which the economy can meet this additional demand for $D_{t}$. The key elasticities determining the response of aggregate imports to an increase in protection will thus be $\kappa$ and $\eta$, although all of the elasticities matter to some extent. On the other hand, the fact that preferences are homothetic implies that $\kappa$ and $\eta$ are irrelevant to the share of 
trade coming from a particular country, such as the UK. The key elasticities determining that will be the $\sigma_{g}$ 's, although $\gamma$ will also matter.

Given that our utility function is (nested) CES, and that our single production function is CET, all of the parameters underlying these functions (i.e. $\alpha$, $\beta_{g t}, \delta_{g c t}$, and $\theta$ ) can be recovered given data on consumption (i.e. $m_{g c t}$ and $D_{t}$ ) and production (i.e. $G D P_{t}, D_{t}$, and $X_{t}$ ), exogenous policy price wedges (i.e. $t_{g c t}, q$, and $v_{g c t}$ ), and the elasticities in the model (i.e. $\eta, \kappa, \gamma$, and $\sigma_{g}$ ). Section 4 will describe our data on consumption, production, and tariffs, while Section 5 derives the elasticities, as well as our estimate of $q$.

\section{Data}

In order to calibrate the model for each year $t$ we need four types of information: imports by commodity and country; trade policy (chiefly tariffs, but also information on non-tariff barriers to trade) by commodity and country; Indian consumption (and production) of the domestic good $D_{t}$; and the elasticities described in Section 3. In this section we describe the data sources used to obtain the first three of these items, which are then used to derive the elasticities in Section 5 .

\subsection{Trade data}

The basic problem with historical trade data is that the trade classifications used by the relevant national authorities are consistent neither across countries nor over time. However, it is sometimes possible to construct import data that correspond to SITC categories: doing so requires that the trade categories reported at the time fall entirely within particular SITC categories and that the available data allow us to capture all imports falling within a given SITC category. We collected data on all Indian imports, between 1923-4 and 1937-8, in 35 distinct 3-digit SITC categories. ${ }^{16}$ These categories were chosen because of their importance in world trade generally, and also because it was possible to consistently calculate import values for each. ${ }^{17}$ In order to accomplish this we hand collected import data from various volumes of the "Annual Statement

\footnotetext{
${ }^{16}$ Indian trade statistics were compiled for fiscal years, beginning on April 1 and ending on March 31. We are using the original Standard International Trade Classification, Revision 1, based on Statistical Office of the United Nations (1951, 1953).

${ }^{17}$ That is, sub-categories of trade we needed to compute these values fell neatly within our 3-digit SITC categories, rather than spanning two or more categories; and we were able to capture all of the imports within each 3-digit category.
} 
of the Sea-Borne Trade of British India with the British Empire and Foreign Countries". ${ }^{18}$ For each year we collected import values for up to 202 individual product categories from 63 countries/sub-regions. In principle this implied collecting 190,890 datapoints, although product categories tended to change over time, some vanishing and others appearing, implying that the actual number of datapoints collected was rather smaller. In addition, many observations were zero. ${ }^{19}$ We were able to aggregate the 202 individual product categories to produce import data for 114 product categories that are consistently defined over time $^{20}$ It is these 114 categories which can in turn be aggregated up to our 35 SITC 3-digit categories. For example, our good number 261001, "Silk, raw", was constructed using eight separate items which appear in the trade statistics between 1923 and 1937, namely "Silk, raw", "Silk. Waste", "Textiles. Silk. Raw and cocoons", "Textiles. Silk. Waste and noils", "Textiles. Silk. Silk, raw and cocoons", "Textiles. Silk. Waste products, including duppion", "Textiles. Silk. Silk, raw and cocoons, Hand reeled" and "Textiles. Silk. Silk, raw and cocoons, Other Sorts". A complicating factor for this good was the fact that the statistics reported an increasingly detailed disaggregation over time, two items at the beginning, and four at the end. It is due to such time-varying disaggregation that we had to aggregate the 202 narrower product categories into a broader and consistently defined set of 114 product categories. Thankfully, there are also series which are presented consistently over time, and for which there is only one original trade statistics item corresponding to one of our 114 product categories. Examples of such categories include "Cotton, raw" and "Wool, raw".

Online Appendix 1 provides full details of how we aggregated the original published trade statistics to produce our final dataset, while Online Appendix 2 lists the 42 partner countries used in our analysis.

Figure 3 shows that the total value of imports in our sample, and the total

\footnotetext{
${ }^{18}$ Prior to financial year 1937-38, the statistics in these volumes referred to the trade not only of British India proper, but of Burma as well. They thus excluded trade between British India and Burma. From 1937-38 onwards, the trade statistics of Burma were published separately. This meant that the Indian statistics included the trade of British India with Burma, and excluded the direct trade of Burma with other countries. The figures recorded in the 193738 volumes were therefore not comparable with those for the earlier volumes. To make the figures comparable across volumes, we additionally hand collected trade data from the Annual Statement of the Sea-Borne Trade and Navigation of Burma for 1937-38. We used these statistics to net out trade between British India and Burma, and to add trade between Burma and the rest of the world to the Indian totals, for each good in our sample.

${ }^{19}$ Where no imports of a particular good from a particular country were listed in the trade statistics we simply assumed that imports were equal to zero.

${ }^{20}$ These 114 categories are the narrowest for which it was possible to generate consistent data over time.
} 
Figure 3: Total and sample Indian imports, 1923-4 to 1937-8

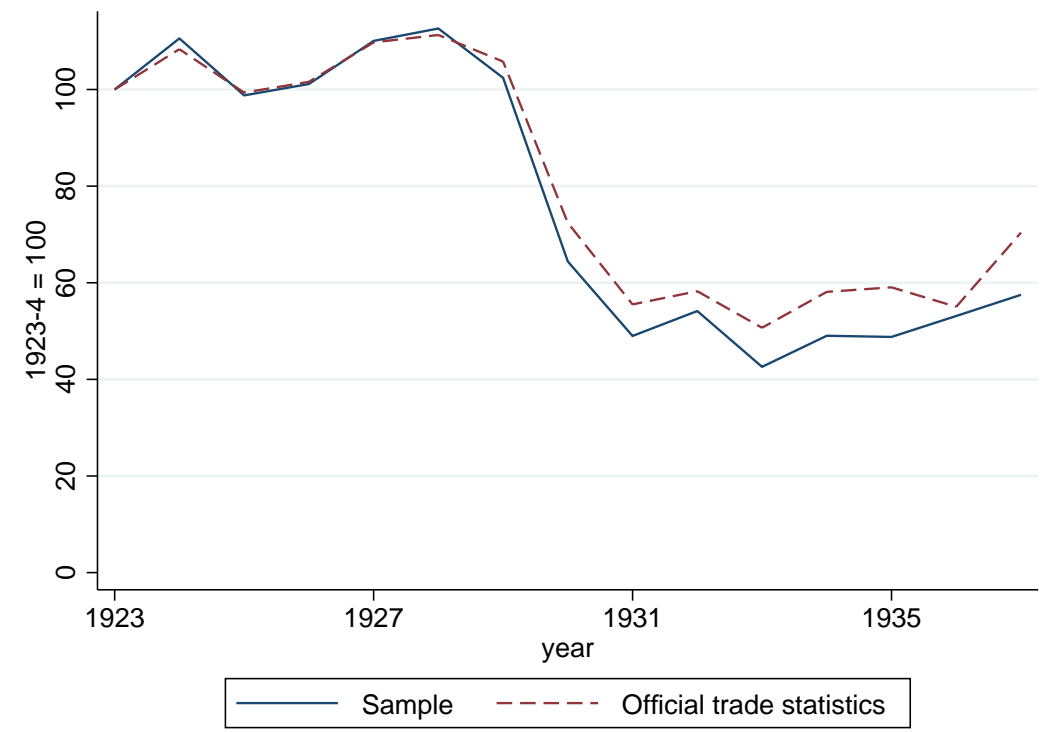

Note: this figure plots an index of the official total value of Indian imports, alongside an index of the total import value for our sample of goods.

Source: Annual Statement of the Sea-Borne Trade of British India with the British Empire and Foreign Countries.

value of imports in the official trade statistics, track each other closely. Our sample captures between $54 \%$ and $67 \%$ of all Indian imports. Figure 4 shows that our sample does a good job of matching the British Empire's share of total Indian imports. ${ }^{21}$

The trade collapse of 1929-33 occurred along the intensive rather than the extensive margin. In 1928-29 there were 817 varieties (particular goods from particular countries) in our dataset; in 1932-3 the number had declined, but only to 792 , a fall of just $3 \%$. When we decompose the trade collapse as in Kehoe and Ruhl (2013), the intensive margin accounts for $100.8 \%$ of the fall in trade between 1928-9 and 1932-3. Our modelling strategy as outlined above thus focusses on the intensive margin. ${ }^{22}$

\footnotetext{
${ }^{21}$ Data for 1937-8 are missing as a result of the reorganization of Burmese and Indian trade statistics.

${ }^{22}$ The figure is $97.5 \%$ for $1928-9$ to $1936-7$. This partly reflects the fact that the data for these two years come from different volumes of the trade statistics; the later volume systematically reported data for fewer national varieties, with some supplier countries being included in the 'Other' category. Even so, it is clear that the action was entirely on the intensive margin.
} 
Figure 4: Total and sample Empire share of Indian imports, 1923-4 to 1936-7

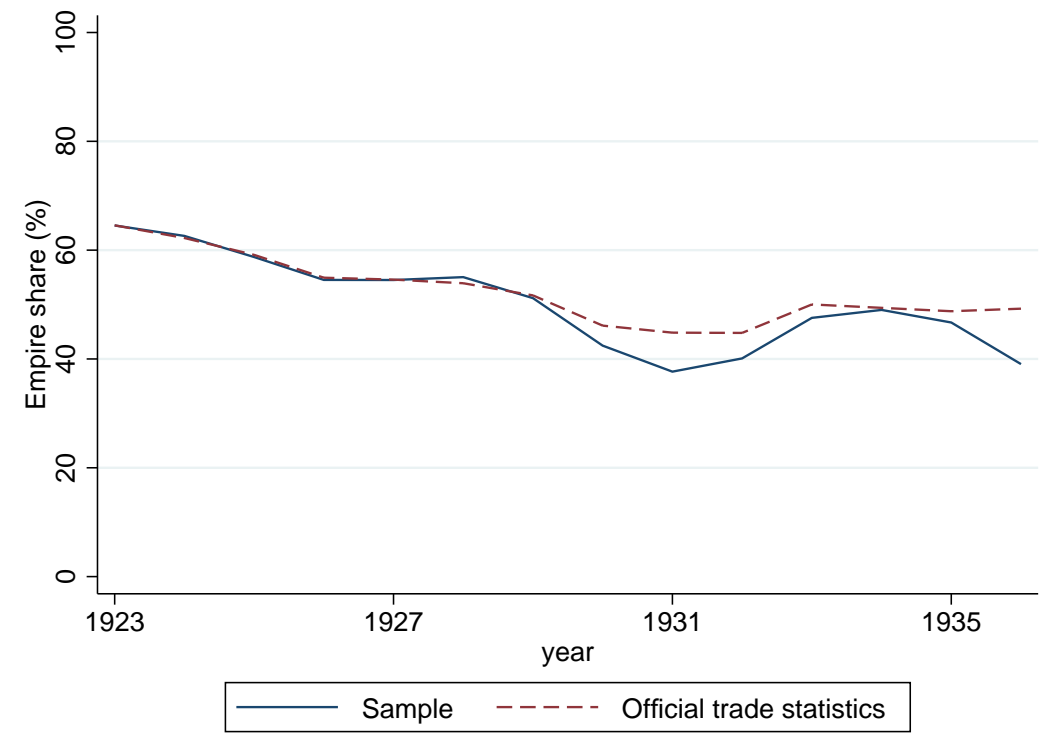

Note: this figure plots the share of the British Empire in total Indian imports, for all goods and for our sample of goods.

Source: Annual Statement of the Sea-Borne Trade of British India with the British Empire and Foreign Countries.

\subsection{Trade policy data}

Tariff information was obtained from various volumes of the Indian Trade Journal. The tariff rates for a given year were published in the supplement to the Trade Journal's final volume of the previous year. We also looked at amendments made to the Indian Tariff Act which were mentioned in the Indian legislation from this period to check for any changes in tariff rates that came into effect in the middle of the year. To account for these mid-year changes we took a weighted average of rates in place prior to and after the change with the weights determined by the month in which the changes took effect. ${ }^{23}$

While some product categories mentioned in the Indian Trade Journal corresponded well with the product categories in the import data, there were cases where the tariff rates were for either a broader or a narrower product category than those in our import data. For example, tariff information was given for

\footnotetext{
${ }^{23}$ Our trade policy data are thus for calendar years starting on January 1, while our trade data are for fiscal years starting on April 1. We use calendar year tariff data since trade policy might be expected to influence trade flows with a lag.
} 
"Grain and pulse, all sorts, including broken grains and pulse, but excluding flour" which was broader than the corresponding import product categories. In this case the rates were applied to all individual products falling under the Grain and Pulse category, unless there were specific exemptions.

Alternately, in cases where tariff information was given for narrower product categories, an unweighted average of the rates was used for the broader import categories. For example, tariff information was given for "Cotton twist and yarn, and cotton sewing or darning thread, of counts above 50s" and "Cotton twist and yarn, and cotton sewing or darning thread, of counts below 50s" which are narrower than the product category "Textiles. Cotton. Twist and Yarn" in our import data. In this case the rates used for Cotton, Twist and Yarn are an unweighted average of the rates of the two categories mentioned above.

While tariffs were mainly ad valorem, for certain goods there were specific rates in place and for some goods there was a mix of both specific and ad valorem rates. Specific rates were expressed in ad valorem terms by dividing the specific rates by the unit value of imports (import value divided by import quantity). Information on non-tariff barriers (i.e. the quota on Japanese cotton piece goods) were obtained from the sources used in Section 2, and are listed (along with the information we use on cartels) in Online Appendix 3.

\subsection{Consumption of the domestic good $D$}

The Net Domestic Product (NDP) of British India (not including Burma) is taken from Sivasubramonian (2000, pp. 429-30). However, as mentioned in footnote 18 above, our trade data include imports into Burma. Hlaing (1964, p. 143) provides NDP data for Burma for the years 1921-22, 1926-27, 1931-32, 1936-37, and 1938-39. This allows us to adjust "Indian" NDP upward so as to include Burma for these five years, and we compute adjustment factors for the intervening years via geometric interpolation (the combined total is around $5 \%$ higher than the NDP for British India alone). In order to compute consumption (and production) of the domestically produced and consumed good $D$ we simply subtract the total value of imports from NDP. We make one adjustment to the data: since our import data only cover a (large and representative) sample of all Indian imports, we scale NDP down by an equivalent amount so as to match the actual import/NDP ratio when calibrating our CGE models. ${ }^{24}$

\footnotetext{
${ }^{24}$ That is to say, we work with a scaled down model of the Indian economy, which captures between $54 \%$ and $67 \%$ of all imports, excludes the other import sectors, and scales down
} 


\section{$5 \quad$ Estimating the elasticities}

In this section we describe how we estimate the elasticities embedded in the model described in Section 3. In order to take account of the fact that they are estimated imprecisely we later perform systematic sensitivity analysis when doing counterfactual analysis (Hillberry and Hummels, 2013, 1243-4). ${ }^{25}$ That is, we repeatedly draw values for these elasticities from normal distributions, with means equal to the point estimates of the elasticities, and standard deviations equal to the standard errors of the coefficients. We are therefore interested in both the point estimates and standard errors of all elasticity estimates in what follows.

\subsection{Estimating the $\sigma_{g}$ 's}

The structural gravity model (e.g. Anderson and Yotov, 2016) and equation (5) imply an expression for imports $m_{g c t}$ into India of good $g$ from country $c$ in year $t$, valued at domestic prices $p_{g c t}^{D}$, of the form

$$
p_{g c t}^{D} m_{g c t} \equiv \tau_{g c t} p_{g c t}^{W} m_{g c t}=\frac{M_{g t} Y_{g c t}}{Y_{g t}}\left(\frac{\tau_{g c t}}{P_{g t} \Pi_{g c t}}\right)^{1-\sigma_{g}}
$$

where $Y_{g c t}$ is the output of good $g$ in country $c$ in year $t$; $Y_{g t}$ is world output of good $g$ in year t; $P_{g t}$ is the inward multilateral resistance term for good $g$ in India in year $t$; and $\Pi_{g c t}$ is the outward multilateral resistance term for good $g$ from country $c$ in year $t$. As in Section $3, M_{g t}$ represents total imports from all countries of good $g$ in year $t$, while $p_{g c t}^{W}$ represents world prices, and $\tau_{g c t}$ the markup of domestic over world prices due to tariffs $t_{g c t}$ and quotas. The trade elasticity is given by $1-\sigma_{g}$ where $\sigma_{g}$ is as before the elasticity of substitution between national varieties of goods, which is what we want to estimate.

Our import data, labelled $V_{g c t}^{W} \equiv p_{g c t}^{W} m_{\text {gct }}$, are c.i.f., and valued at world prices inclusive of transport and other trade costs not related to Indian trade policies. We are not interested in these costs since we are holding them fixed in our analysis. We do not have enough degrees of freedom to estimate $\sigma_{g}$ separately for each of our 114 goods $g$, and therefore let $\sigma_{g}=\sigma \forall g$. In a robustness exercise we estimate elasticities across nine categories of goods $h$, assuming a

the size of the domestic economy so as to match the actual baseline openness of the Indian economy in each year.

${ }^{25}$ Lai and Trefler (2002) use econometric methods to estimate the mean and standard errors of welfare gains associated with trade liberalization. 
common elasticity $\sigma_{h}$ for all goods within a category (i.e. $\sigma_{g}=\sigma_{h} \forall g \in h$ ). The nine categories are grain, animal products, machinery, minerals, textiles, miscellaneous inputs, miscellaneous industry, food oils, and colonial goods. We also make use of these categories when estimating a common $\sigma$ across all goods, as will be explained below. ${ }^{26}$

Dividing through equation (7) by $\tau_{g c t}$, substituting for $\tau_{g c t}$ using equation (6), and taking logs, yields the equation that we should ideally be estimating:

$$
\begin{gathered}
\ln \left(V_{g c t}^{W}\right)=\ln \left(M_{g t}\right)+\ln \left(Y_{g c t}\right)-\ln \left(Y_{g t}\right)-\sigma \ln \left(1+t_{g c t}\right)-\sigma \ln (q) v_{g c t} \\
-(1-\sigma) \ln \left(P_{g t}\right)-(1-\sigma) \ln \left(\Pi_{g c t}\right)+u_{g c t}
\end{gathered}
$$

where as before $q-1$ is the ad valorem tariff equivalent of the quota on Japanese cotton piece goods; $v_{g c t}$ is a dummy variable indicating whether or not imports of good $g$ from country $c$ are subject to the quota in year $t$; and $u_{g c t}$ is the error term. The key independent variables in the regression are thus $\ln \left(1+t_{g c t}\right)$ and $v_{g c t}$ : if the coefficients on these variables are represented by $b_{1}$ and $b_{2}$, our estimate of $\sigma$ will be $-b_{1}$, while our estimate of $q$ will be $\exp \left(b_{2} / b_{1}\right)$.

Standard practice is to include fixed effects to account for the multilateral resistances, and so we include fixed effects which vary by good and year, $d_{g t}$. These control for $M_{g t}, Y_{g t}$, and $P_{g t}$ in equation (8). Intuitively, by controlling for the total imports of particular goods in particular years we are focussing on the margin of substitution between different national varieties of the same good, which is what we want to do when estimating $\sigma$. Unfortunately, since we only have import data for India we cannot include fixed effects varying by good, country, and year, as would be required to control for $\Pi_{g c t}$ (and $Y_{g c t}$ ). We do however experiment with a wide range of fixed effects (see below).

Another potential problem that we face, in common with other papers using tariff data to estimate trade elasticities, is the possible endogeneity of tariffs. ${ }^{27}$

\footnotetext{
26 'Grain' includes barley, wheat and rice (SITC categories 041-043); 'Animal' includes butter and meat (SITC categories 012 and 023); 'Machinery' includes SITC categories 711, 712, 714716, and 721; 'Minerals' includes metals, coal and petroleum (SITC categories 311-313, 681, and 682); 'Textiles' includes both yarn and cloth (SITC codes 651-653); 'Miscellaneous inputs' includes such items as fertilisers, rubber, hides and skins, raw cotton and silk, and hair (SITC codes 211, 231, 261-263, 271, and 561); 'Miscellaneous industry' includes vehicles and rubber manufactures, including tyres (SITC codes 629, 713, and 732); 'Food oils' includes oils and oilseeds of various kinds (SITC codes 221 and 412); and 'Colonial' includes coffee, sugar, tea and tobacco (SITC categories 061, 071, 074, and 121). The categorization is the same as that used in de Bromhead et al. (2019).

${ }^{27}$ See for example the papers listed in the recent Handbook chapter by Caliendo and Parro
} 
To some extent these problems are mitigated by our abundant use of fixed effects, but we acknowledge that they are not eliminated, especially given that we cannot include good-country-time fixed effects. For example, if a country experienced a positive productivity shock for a particular good in a particular year, India might raise tariffs to protect itself against higher imports of that particular variety. In this case our elasticity estimates would be biased downward, and indeed the common presumption is that trade policy endogeneity biases estimates of the impact of trade policy on imports down (Trefler, 1993). The bias could however go the other way. For example, if a positive taste shock led India to lower tariffs on imports of a particular good, but the country was constrained from lowering tariffs on foreign (i.e. non-British) varieties, then imports from Britain would rise in part because of the taste shock, thus biasing our estimates upwards. ${ }^{28}$

Aside from the data constraints which we face, it is difficult to think of a suitable instrument for Indian tariffs, since obvious candidates (such as foreign tariffs) themselves directly influenced Indian imports by diverting trade flows to and from the country. In this paper we follow a different approach. Recall that in 1932 the Indian government agreed, somewhat reluctantly, to extend to British colonies tariff preferences which it had accorded to Britain. ${ }^{29}$ It also agreed to grant preferences to the colonies on a further list of goods specified in Schedule $\mathrm{H}$ of the UK-Indian Agreement. ${ }^{30}$ It is possible that tariffs on imports from the UK (with whom India negotiated trade agreements at Ottawa) were endogenous, as well as the Schedule $\mathrm{H}$ tariff preferences India agreed to extend to the colonies. It is also possible that Indian tariffs on foreign (i.e. non-Empire) and Dominion goods were endogenous. But from 1932 onwards, the colonies were (except in the case of Schedule $\mathrm{H}$ goods) the beneficiaries of tariff reductions aimed in the first instance at imports from Britain. It seems reasonable to assume that these colonial tariff changes were, if not completely exogenous, at least a lot more exogenous than tariffs on other categories of imports.

We therefore define a dummy variable Colony gct which is equal to one if the (2021, p. 22).

${ }^{28} \mathrm{We}$ are grateful to a referee for raising this possibility.

${ }^{29}$ This was subject to those colonies reciprocating, but since the UK agreed to "invite the Governments of the non-self-governing Colonies and Protectorates to accord to India any preference which may, for the time being, be accorded to any other part of the British Empire" this qualification was not particularly constraining.

${ }^{30}$ This included the following goods in our dataset (with their numerical identifiers listed alongside): Coffee 71001; Tea 74001; Tobacco Unmanufactured 121001; Oilseeds, copra or coconut kernel 221001; Oilseeds, groundnuts 221002; Oilseeds, linseeds 221003; Oilseeds, sesamum 221004; Oilseeds, tea 221005; Oilseeds, others 221006; Non- Essential Vegetable Oils 412001; Coir Manufactures 651001. 
Table 1: PPML gravity estimates

\begin{tabular}{lccc}
\hline & $(1)$ & $(2)$ & $(3)$ \\
\hline Colony* $\log (1+$ tariff $)$ & -3.474 & -3.419 & -3.010 \\
$(1-\text { Colony })^{*} \log (1+$ tariff $)$ & -1.702 & -3.032 & -2.805 \\
& $(1.531)$ & $(1.220)$ & $(0.997)$ \\
Quota on Japanese piece goods & -0.690 & -1.170 & -1.520 \\
& $(0.205)$ & $(0.170)$ & $(0.241)$ \\
Cartel & -0.982 & -3.087 & -0.0765 \\
& $(0.602)$ & $(1.572)$ & $(0.283)$ \\
Constant & -1.472 & -1.150 & -1.267 \\
No. of observations & $(0.245)$ & $(0.205)$ & $(0.170)$ \\
\hline
\end{tabular}

Note: Dependent variable is the value of imports by good, country, and year. Estimates computed using ppmlhdfe. Robust standard errors clustered by country in parentheses. The specification in Column (1) includes good-year, good-country, and country-year fixed effects. Column (2) includes good-year, good-country-period, and country-year fixed effects. Column (3) includes good-year, good-country-period, and country-year-category fixed effects. Categories are the nine commodity groups discussed in the text: grain, animal products, machinery, minerals, textiles, miscellaneous inputs, miscellaneous industry, food oils, and colonial goods. The three periods are 1923-29, 1930-32, and 1933-37.

country concerned is a colony, the year is 1932 or later, and the good is not one of those mentioned in Schedule H, and zero otherwise. Our estimating equation becomes

$$
\begin{aligned}
\ln V_{g c t}^{W}=b_{o}+ & b_{1} \ln \left(1+t_{g c t}\right) \times \text { Colony }_{g c t}+b_{2} \ln \left(1+t_{\text {gct }}\right) \times\left(1-\text { Colony }_{g c t}\right) \\
& +b_{3} v_{g c t}+\{\text { controls }\}+\{\text { fixedeffects }\}+u_{g c t}
\end{aligned}
$$

We follow Santos Silva and Tenreyro (2006) and use the ppmlhdfe estimator available in Stata (Correia et al. 2019a,b) to estimate (9). ${ }^{31}$ Since tariffs are more likely to be exogenous if Colony $y_{g c t}=1$, we let $-b_{1}$ be our estimate of $\sigma$, and $\exp \left(b_{3} / b_{1}\right)$ be our estimate of $q$. We control for whether or not there was an international cartel in place, involving India and trade partner $c$, for good $g$ in year $t$.

The results are presented in Table 1. As mentioned earlier, all specifications include good-time fixed effects. These control for any supply-side or demandside shifts affecting total imports of a commodity over time, as well as any product-invariant characteristics or common time trends. Column (1) also in-

\footnotetext{
${ }^{31}$ Our standard errors are clustered by country.
} 
cludes good-country (i.e. variety) and country-time fixed effects. By including the former we are ensuring that identification occurs along the time dimension alone, an important consideration given the possibility that some varieties may have faced systematically higher tariffs over time than others. Variety fixed effects also account for all time-invariant factors influencing imports of particular varieties, which may include Indian tastes, foreign supply-side factors, and variety-specific transport costs. Country-time fixed effects control for such factors as GDP, exchange rates, and country remoteness.

Column (2) retains the good-year and country-year fixed effects of Column (1), but replaces its good-country fixed effects with good-country-period fixed effects. We consider three periods, corresponding to the pre-Depression years 1923-29, the Depression years 1930-32, and the recovery years 1933-37. In this manner we are controlling for any variety-specific impact of the Depression and the recovery that followed. Defining periods in this way also controls for the impact of the boycotts of 1930-32 as well as their potential long-run aftermath (Wolcott, 1991). Finally, Column (3) presents our preferred and most demanding specification. Once again it includes good-year and good-country-period fixed effects, but now replaces the country-time fixed effects of Column (1) with country-time-product category fixed effects. The product categories concerned are the nine discussed earlier, into one of which each of our 114 goods falls: grain, animal products, machinery, minerals, textiles, miscellaneous inputs, miscellaneous industry, food oils, and colonial goods.

As can be seen, our preferred specification yields an estimate of $b_{1}$ of -3.01 , implying a trade elasticity of -2 . The estimate of $b_{2}$ is smaller, at -2.8 . This is a consistent finding across specifications. If endogeneity is a problem when Colonygct $=0$, these results suggest that its impact is to bias the estimated impact of tariffs downwards, in line with Trefler (1993). The two coefficients are however never statistically significantly different from each other.

We thus take 3.01 as our preferred point estimate of $\sigma$, with a corresponding standard error of 1.067. This estimate, together with the coefficient on our quota variable, implies that the quota on Japanese cotton piece goods was equivalent to an ad valorem tariff of $65.7 \%$.

\subsection{Choosing values for $\gamma$}

We assume that $\gamma$, the mid-level elasticity of substitution between different Armington aggregates of imported goods, is equal to 1, but in Online Appendix 
4 we show that our results would be qualitatively unchanged if we let $\gamma$ be equal to either 0.5 or 2 .

\subsection{Estimating $\kappa$}

We ran the OLS regression

$$
\ln \left(m_{t}\right)=-\kappa \ln \left(1+t_{t}\right)+u_{t}
$$

where $m_{t}$ is the value of imports in year t expressed as a share of total private expenditure on both domestic and imported goods, $u_{t}$ is the error term, and $t_{t}$ is the unweighted average tariff estimated for our sample of goods. The method produced an estimate of $\kappa$ of 1.073 , with a standard error of $0.376 .{ }^{32}$

\subsection{Choosing values for $\eta$}

Finally, we need to choose values for $\eta$, the supply-side elasticity of transformation between domestic output and exports. Here we proceed as in de Bromhead et al. (2019): we use the fact that $\eta=\varepsilon_{S} /\left(1-\alpha^{X}\right)$, where $\alpha^{X}=1-\alpha^{D}$ is the share of exports in total production, and assume (based on Tokarick 2014) that the $\log$ of $\varepsilon_{S}$ is normally distributed, with mean 0.403 and standard deviation 0.468 .

\section{Counterfactual results}

In this section we explore the impact of the changes in Indian trade policy following the establishment of the Tariff Board on the recommendation of the Indian Fiscal Commission. Since the first tariffs recommended by the Board came into effect in 1924, we focus on the impact of trade policy changes from that year onwards. To this end we first embed the elasticities described in the previous section into the fifteen models (one for each fiscal year from 1923-4 to 1937-8 inclusive) outlined in Section 3. We calibrate the models using the tariffs, quotas, imports, GDP, and domestic consumption that we actually observe for

\footnotetext{
${ }^{32}$ Total private expenditure on domestic goods was calculated by multiplying GDP by the ratio of gross output to GDP at factor cost in 1951-2, and then subtracting the value of total exports (both government and private). Gross output was taken to be equal to GDP at factor cost plus total material inputs into all sectors. The 1951-2 input-output data are taken from Ramana (1969, pp. 46-7). Sources for interwar GDP are as given in Section 4.3 of the text. The aggregate Indian trade data are taken from the Annual Statement of the Sea-Borne Trade of British India.
} 
each year, and verify that the model can replicate the benchmark equilibrium. ${ }^{33}$ Finally, we solve the model for each year, assuming counterfactually that trade policy was identical to what it was in 1923 throughout (that is, that ad valorem tariffs in each year were the same as in 1923, and that no quotas were in place). By comparing these counterfactual, constant-policy equilibria with the actual equilibria we can infer the impact on trade flows of the shifts in trade policy that took place after 1923. We repeat this procedure 1000 times for each year, each time drawing new elasticity values from normal distributions whose means and standard errors were described in the previous section. ${ }^{34}$ The result is 1000 estimates of the impact of trade policy on trade flows for each year, allowing us not only to calculate the impact of policy, but to assess how tightly estimated that impact is.

\subsection{The impact of trade policy on the total value of im- ports}

We begin with the impact of tariffs and quotas on the total value of Indian imports. Figure 5 plots the percentage impact on imports from 1923 to 1937. In each case the figure shows the percentage by which actual imports differed from what they would have been, had trade policies remained fixed at their 1923 level. It plots not only the mean estimated impact across all 1000 repetitions for each year, but the 5 th, 25 th, 75 th, and 95 th percentile impacts also. In this manner it indicates how sensitive our results are to the fact that our elasticities are imprecisely estimated.

As can be seen from Figure 5, by 1932 onwards protectionism was lowering Indian imports by roughly $10 \%$ on average, although the effect is imprecisely estimated (mostly reflecting the imprecision with which we estimated $\kappa$ ). The mean estimate for 1934 was $11.6 \%$, while the 25 th and 75 th percentile impacts were 8.7 and $14.5 \%$ respectively. ${ }^{35}$ The value of Indian private imports fell by $49.3 \%$ between 1923 and the trough (1933). Our mean estimate is that

\footnotetext{
${ }^{33}$ That is, we solve the model using the tariffs and quotas that were actually in place in the year in question, and verify that the model generates the imports that were actually observed in that year.

${ }^{34}$ If a draw produces a negative elasticity we constrain the elasticity to be equal to zero. In the case of $\eta$ we draw 1000 replications of the $\log$ of $\varepsilon_{S}$ and calculate $\eta$ using the formula in Section 5.4 .

${ }^{35}$ The 5 th and 95 th percentile impacts were 3.5 and $18.5 \%$ respectively. The gap between these upper and lower bound estimates depends not just on the standard error of the elasticity estimates, but on the size of the shock being imposed on the model, which is why the gap is so much smaller before 1930 .
} 
Figure 5: Impact of post-1923 shift in protection on total Indian imports

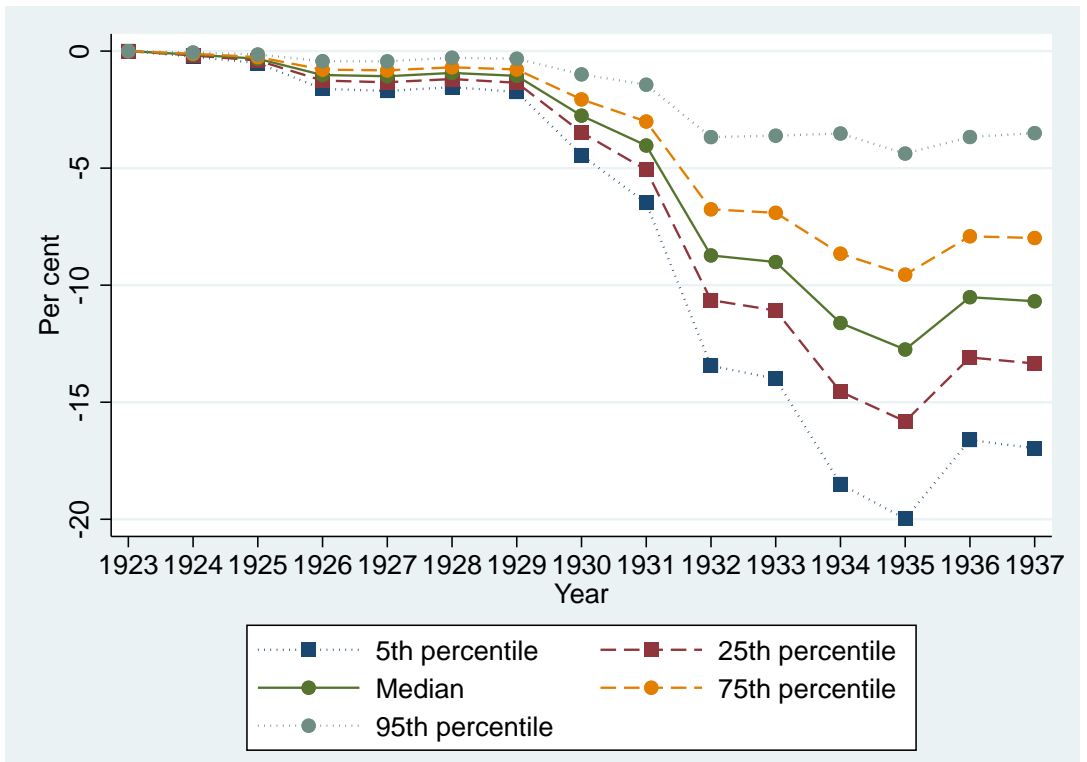

Note: this graph plots the percentage difference between the total Indian imports actually observed in each year, and the counterfactual level that would have obtained had tariffs and quotas remained at their 1923 levels throughout. This number is calculated 1000 times for each year, using different elasticities as described in the text. We plot the mean estimated impact of changes in trade policy since 1923, along with the 5th, 25th, 75th, and 95th percentiles.

protection lowered Indian imports by $9 \%$ in 1933, implying that it accounted for almost a fifth of that decline, and its impact was larger still in 1934 and 1935. India was a developing economy and a colony, very different from the rich industrial economies that have been the focus of previous analysis. It is striking therefore that the results are quite similar to those obtained by Irwin (1998) for the United States, and de Bromhead et al. (2019) for the UK.

\subsection{The impact of trade policy on the share of Indian im- ports coming from the UK}

The previous subsection showed that protection lowered Indian imports during the 1920s and 1930s. But tariffs did not just increase during this period, they did so in a discriminatory fashion. Not only did UK exports face lower tariffs than non-British countries, but Japanese textile producers were subjected to quantitative restrictions from 1934 onwards. What was the impact of trade 
discrimination on the UK's share of Indian imports?

Figure 6: Percentage impact of post-1923 shift in protection on the UK share of Indian imports

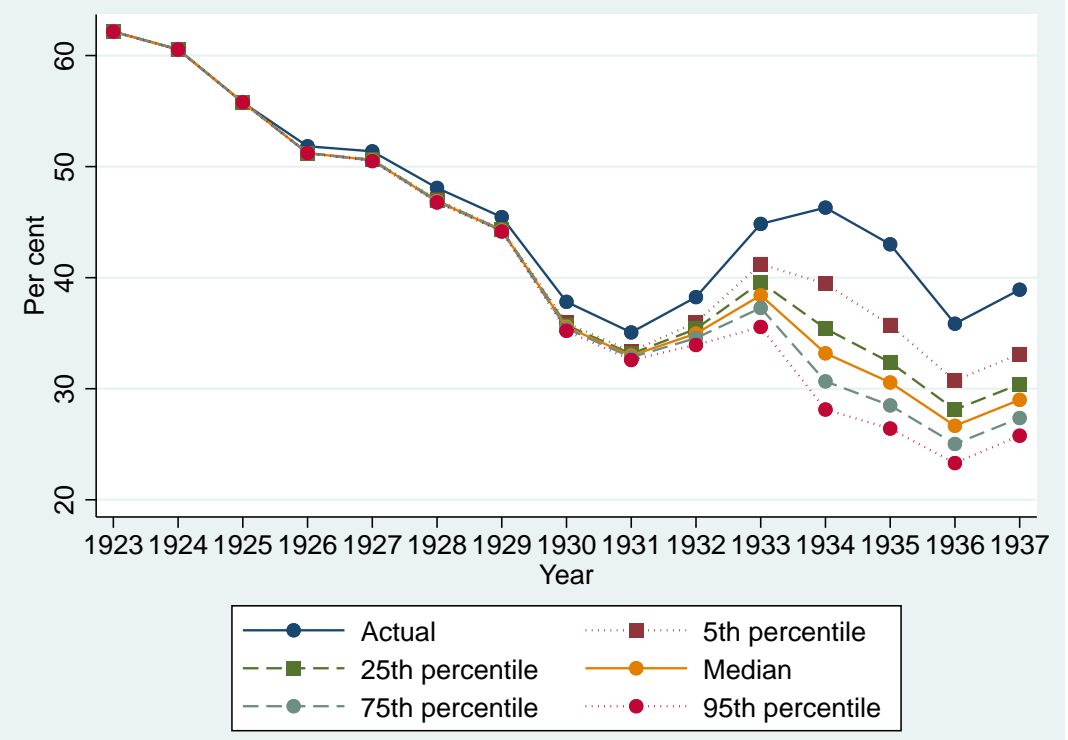

Note: this graph plots the UK's actual share of Indian imports in each year, and the counterfactual share that would have obtained had tariffs and quotas remained at their 1923 levels throughout. The latter number is calculated 1000 times for each year, using different elasticities as described in the text. We plot the mean estimated impact of changes in trade policy since 1923 , along with the 5 th, 25 th, 75 th, and 95 th percentiles.

Figure 6 plots the UK's actual share of Indian imports between 1923 and 1937, as well as the counterfactual share that it would have enjoyed had Indian protection remained at its 1923 levels. Once again the figure plots not only the mean counterfactual share for each year, calculated across the 1000 replications, but the 5th, 25th, 75th, and 95th percentile impacts also. As can be seen, the actual and counterfactual shares remain fairly close until 1932 but diverge sharply thereafter. In 1934, to take the same example as in the previous subsection, the UK accounted for $46.3 \%$ of Indian imports. However, if protection had remained at its 1923 level, the UK would only have accounted for $33.2 \%$ according to our mean estimate. Reflecting the fact that $\sigma$, which is what really matters for the UK share, is relatively precisely estimated, our estimates of the counterfactual UK share vary less across replications than the estimates in Figure 5. The 25th and 75th percentile counterfactual shares are 35.4 and $30.7 \%$ respectively, while the 5 th and 95 th percentile estimates are 
Figure 7: Percentage impact of post-1923 shift in protection on total UK exports to India

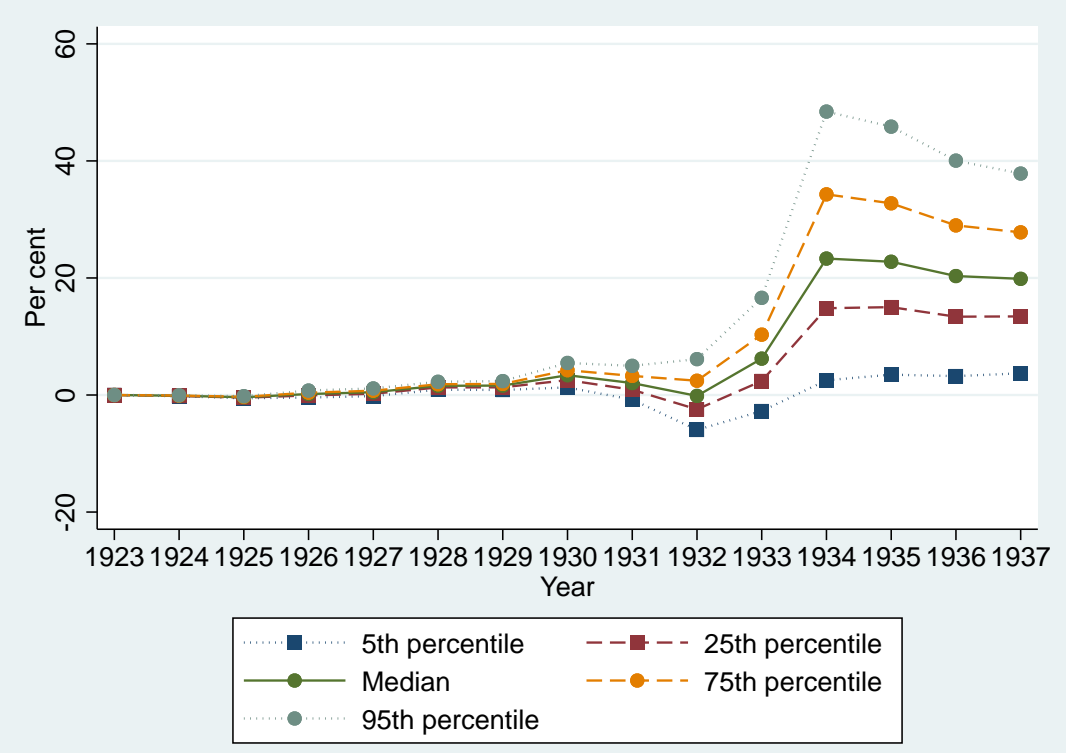

Note: this graph plots the percentage difference between the total UK exports to India actually observed in each year, and the counterfactual level that would have obtained had tariffs and quotas remained at their 1923 levels throughout. This number is calculated 1000 times for each year, using different elasticities as described in the text. We plot the mean estimated impact of changes in trade policy since 1923, along with the 5th, 25th, 75th, and 95 th percentiles.

39.5 and $28.1 \%$ respectively. By the mid-1930s protection was boosting the UK share of Indian imports by more than ten percentage points, or by more than a third.

\subsection{The impact of trade policy on the value of UK exports to India}

Indian protection increased the UK's share of a shrinking pie. What was the net impact on total British exports to India? Figure 7 plots the percentage impact of the post-1923 shift in Indian protection on UK exports to India. As can be seen, the fact that UK exporters to India faced higher tariffs was less important than the fact that foreign exporters faced even higher levels of protection. The net impact on total UK exports to India was clearly positive from 1934 onwards. Our mean estimate suggests that Indian protection boosted UK exports to that 
Figure 8: Percentage impact of post-1923 shift in protection on total UK cotton cloth exports to India

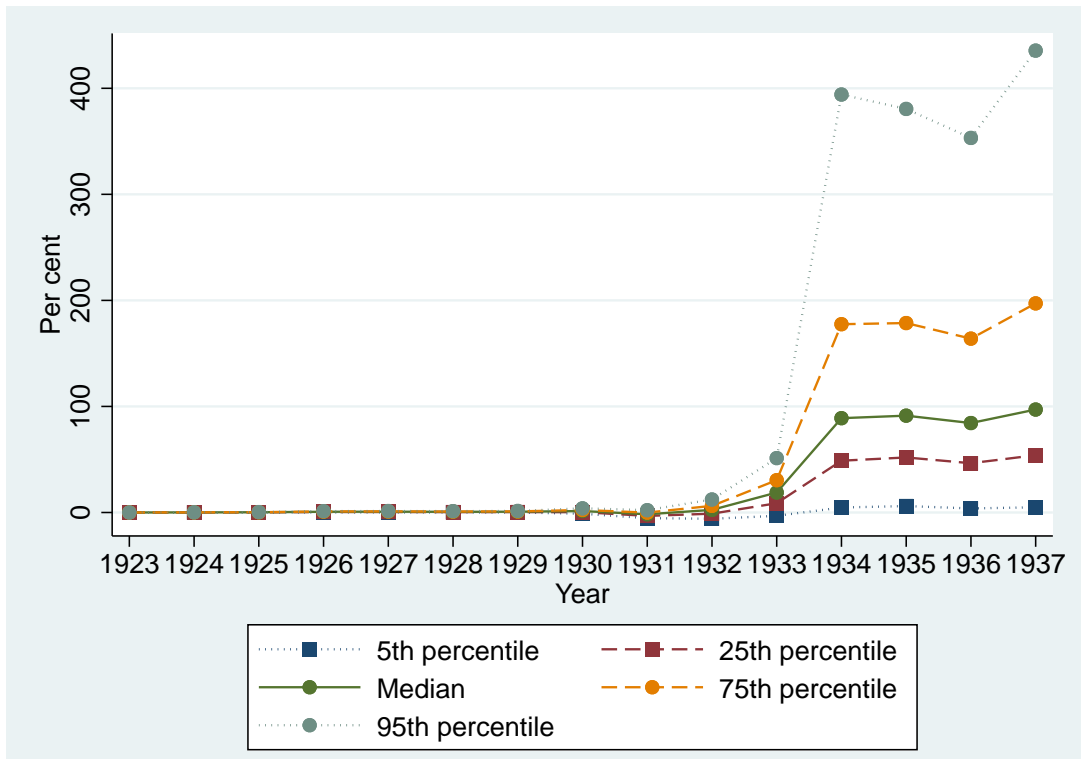

Note: this graph plots the percentage difference between the total UK cotton cloth exports to India actually observed in each year, and the counterfactual level that would have obtained had tariffs and quotas remained at their 1923 levels throughout. This number is calculated 1000 times for each year, using different elasticities as described in the text. We plot the mean estimated impact of changes in trade policy since 1923, along with the 5th, 25th, 75th, and 95th percentiles.

country by $23.3 \%$ in 1934 , with 25 th and 75 th percentile estimates of 14.8 and $34.3 \%$ respectively. ${ }^{36}$

Far from hurting the UK textile industry, Indian protection benefited it (Figure 8). Our mean estimate suggests that total UK exports of cotton cloth were $88.9 \%$ higher in 1934 than they would have been if protection had remained at its 1923 level (with 25th and 75th percentile estimates of 48.8 and $177.6 \%$ respectively). ${ }^{37}$

India was an important market for the UK: in 1934 it took over $9 \%$ of total UK exports, and $20 \%$ of its cotton cloth exports. ${ }^{38}$ Our estimated impacts are thus equivalent to $2 \%$ of total UK exports, and to more than $15 \%$ of total UK

\footnotetext{
${ }^{36}$ The 5 th and 95 th percentile impacts were 2.5 and $48.4 \%$ respectively.

${ }^{37}$ The 5 th and 95 th percentile impacts are 4.7 and $394.1 \%$ respectively.

${ }^{38}$ Statistical Office of the Customs and Excise Department (United Kingdom) (1937, pp. 175-177) (totals); U.K. Parliamentary Papers (1934-35, pp. 830-831) (cottons).
} 
Figure 9: Percentage impact of post-1923 shift in protection on total Japanese exports to India

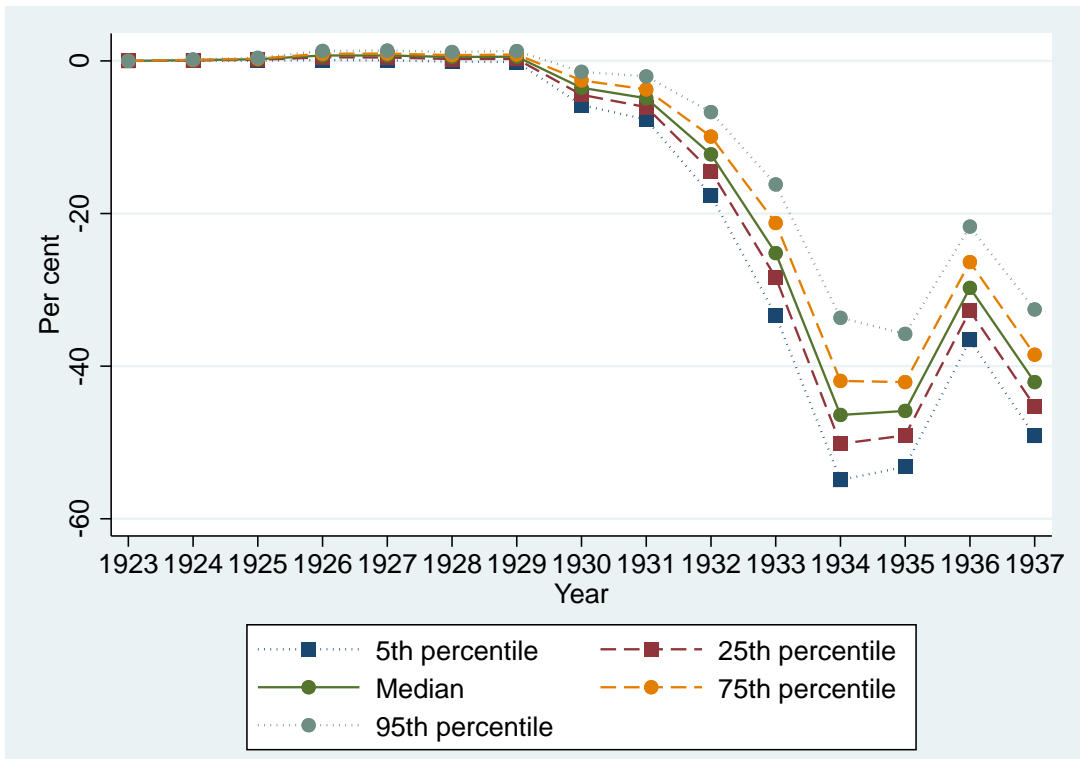

Note: this graph plots the percentage difference between the total Japanese exports to India actually observed in each year, and the counterfactual level that would have obtained had tariffs and quotas remained at their 1923 levels throughout. This number is calculated 1000 times for each year, using different elasticities as described in the text. We plot the mean estimated impact of changes in trade policy since 1923, along with the 5th, 25th, 75th, and 95 th percentiles.

cotton textile exports. Whether or not the Indian fiscal autonomy convention was a "self-denying ordinance" from the British point of view, Indian trade policy in the 1930s boosted exports from the UK to its largest colony.

\subsection{Impact on Japan}

Indian protection lowered imports but Lancashire cotton interests benefited. The big losers were those countries outside the British Empire that now faced discrimination, such as Japan. Figure 9 plots the impact of Indian protection on aggregate Japanese exports to that country. Our mean estimate suggests that protection lowered total Japanese exports to India in 1934 by $46.4 \%$. The impact is relatively precisely estimated. ${ }^{39}$ Figure 10 plots the impact on Japanese

\footnotetext{
${ }^{39}$ The 5 th, 25th, 75th and 95th percentile estimates are 33.7, 41.9, 50.2 and 54.9\% respectively.
} 
Figure 10: Percentage impact of post-1923 shift in protection on total Japanese cotton cloth exports to India

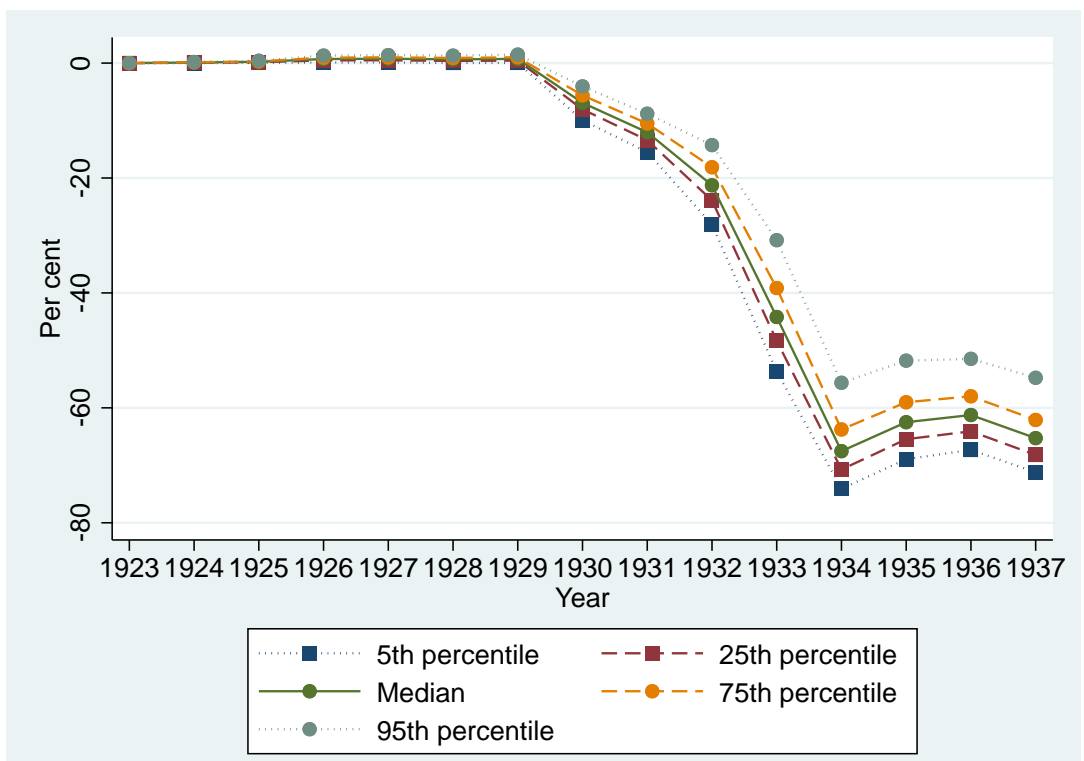

Note: this graph plots the percentage difference between the total Japanese cotton cloth exports to India actually observed in each year, and the counterfactual level that would have obtained had tariffs and quotas remained at their 1923 levels throughout. This number is calculated 1000 times for each year, using different elasticities as described in the text. We plot the mean estimated impact of changes in trade policy since 1923, along with the 5th, 25th, 75th, and 95th percentiles.

cotton cloth exports: according to our mean estimate, in 1934 protection was reducing these by $67.5 \%{ }^{40}$

These effects were large enough to have a noticeable impact on total Japanese exports. India accounted for almost $11 \%$ of total Japanese exports in 1934, and for almost $14 \%$ of its cotton textile exports. ${ }^{41}$ Our estimated impacts are thus equivalent to $5 \%$ of total Japanese exports, and over $9 \%$ of total Japanese cotton cloth exports.

\footnotetext{
${ }^{40}$ The 5 th, 25 th, 75 th and 95 th percentile estimates are 55.6, 63.8, 70.7 and $74.1 \%$ respectively.

${ }^{41}$ Department of Finance (Japan) (1935, pp. 111-156 (cotton piece goods), 396 (total exports)).
} 


\section{Conclusion}

Empires promoted trade between their members. One possible explanation for this is that imperial powers imposed trade policies on their colonies which boosted trade between them. Interwar India offers a fascinating example of a colony being granted tariff autonomy in advance of independence. Whether this benefited or hurt British export interests has been the subject of much historical debate, but little quantitative analysis. It is unsurprising that partial equilibrium analyses, relating tariffs facing British exporters to Indian imports from the UK, have found that higher tariffs led to lower imports. However, such analyses ignore the fact that Indian protection was discriminatory. Far from lowering imports from Britain, Indian protection during this period increased them: granting India fiscal autonomy did not imply the "deliberate surrender" of a key British export market. While the "trading capital" stressed by Head, Mayer and Ries (2010) may have played an important role in boosting intraimperial trade flows, this episode shows that trade policy could also have a significant impact, even in the apparently most unpromising of circumstances.

Most existing studies have found that the protection of the 1930s had only modest effects on the volume and geographical composition of international trade. This study, based on granular data on trade flows and trade policy, reaches a rather different conclusion. Discriminatory trade policy had a significant impact on the composition of India's imports, and on different countries' exports to that market. This in turn played an important role in exacerbating the geopolitical tensions of the time. Imperial trade blocs may have promoted trade between members, but this was at the expense of outsiders who became increasingly frustrated as the decade wore on. In particular, given our results

it is hardly surprising that Indian protectionism was a major additional irritant in Anglo-Japanese diplomatic relations, at a time when international tensions were rising anyway (Osamu, 2000). 


\section{References}

Amiti, Mary, Stephen J. Redding and David E. Weinstein. 2019. "The Impact of the 2018 Tariffs on Prices and Welfare." Journal of Economic Perspectives $33(4): 187-210$.

Anderson, James E. and J. Peter Neary. 1996. "A New Approach to Evaluating Trade Policy." The Review of Economic Studies 63(1):107-125.

Anderson, James E. and Yoto V. Yotov. 2016. "Terms of Trade and Global Efficiency Effects of Free Trade Agreements, 1990-2002." Journal of International Economics 99:279-298.

Arthi, Vellore, Markus Lampe, Ashwin R. Nair and Kevin Hjortshøj O’Rourke. 2020. "The Impact of Interwar Protection: Evidence from India." National Bureau of Economic Research Working Paper Series No. 27178.

Broadberry, Stephen and Alexander Klein. 2012. "Aggregate and Per Capita GDP in Europe, 1870-2000: Continental, Regional and National Data with Changing Boundaries." Scandinavian Economic History Review 60(1):79-107.

Broda, Christian and David E. Weinstein. 2006. "Globalization and the Gains From Variety." The Quarterly Journal of Economics 121(2):541-585.

Caliendo, Lorenzo and Fernando Parro. 2015. "Estimates of the Trade and Welfare Effects of NAFTA." The Review of Economic Studies 82(1):1-44.

Caliendo, Lorenzo and Fernando Parro. 2021. "Trade Policy." National Bureau of Economic Research Working Paper Series No. 29051.

Casler, Don and Nikhar Gaikwad. 2019. "The Interests of India Demand Protection': Democratization and Trade Policy Under Empire." Mimeo, Columbia University .

Chatterji, Basudev. 1992. Trade, Tariffs, and Empire : Lancashire and British Policy in India 1919-1939. Delhi: Oxford University Press.

Chaudhary, Latika, Bishnupriya Gupta, Tirthankar Roy and Anand V. Swamy. 2015. A New Economic History of Colonial India. London: Routledge.

Chaudhuri, K. N. 1983. Foreign Trade and Balance of Payments (1757-1947). In The Cambridge Economic History of India: Volume 2: c.1751-c.1970, 
ed. Dharma Kumar and Meghnad Desai. Cambridge: Cambridge University Press pp. 804-877.

Conesa, Juan Carlos, Matthew J. Delventhal, Pau S. Pujolas and Gajendran Raveendranathan. 2021. "The cost of trade disruptions at different stages of development." Mimeo .

Correia, Sergio, Paulo Guimarães and Thomas Zylkin. 2019a. "Verifying the Existence of Maximum Likelihood Estimates for Generalized Linear Models." arXiv 1903.01633.

Correia, Sergio, Paulo Guimarães and Thomas Zylkin. 2019b. "ppmlhdfe: Fast Poisson Estimation with High-Dimensional Fixed Effects." arXiv 1903.01690.

de Bromhead, Alan, Alan Fernihough, Markus Lampe and Kevin Hjortshøj O'Rourke. 2019. "When Britain Turned Inward: The Impact of Interwar British Protection." American Economic Review 109(2):325-352.

Department of Finance (Japan). 1935. Annual Return of the Foreign Trade of Japan. Part I. Tokyo: Department of Finance.

Dewey, Clive. 1978. The End of the Imperialism of Free Trade: The Eclipse of the Lancashire Lobby and the Concession of Fiscal Autonomy to India. London: Athlone Press for the Institute of Commonwealth Studies pp. 35-67.

Drummond, Ian M. 1972. British Economic Policy and the Empire, 1919-1939. London, New York: George Allen and Unwin.

Dye, Alan and Richard Sicotte. 2006. "How brinkmanship saved Chadbourne: Credibility and the International Sugar Agreement of 1931." Explorations in Economic History 43(2):223-256.

Eichengreen, Barry and Douglas A. Irwin. 1995. "Trade Blocs, Currency Blocs and the Reorientation of World Trade in the 1930s." Journal of International Economics 38(1-2):1-24.

Estevadeordal, Antoni, Brian Frantz and Alan M. Taylor. 2003. "The Rise and Fall of World Trade, 1870-1939." The Quarterly Journal of Economics 118(2):359-407.

Fajgelbaum, Pablo D., Pinelopi K. Goldberg, Patrick J. Kennedy and Amit K. Khandelwal. 2020. "The Return to Protectionism*." The Quarterly Journal of Economics 135(1):1-55. 
Fontagné, Lionel, Houssein Guimbard and Gianluca Orefice. 2022. "Tariffbased product-level trade elasticities." Journal of International Economics 137:103593.

Goldberg, P. K. and N. Pavcnik. 2016. The Effects of Trade Policy. In Handbook of Commercial Policy, ed. Kyle Bagwell and Robert W. Staiger. Vol. 1 Amsterdam: North-Holland pp. 161-206.

Gowa, Joanne and Raymond Hicks. 2013. "Politics, Institutions, and Trade: Lessons of the Interwar Era." International Organization 67(03):439-467.

Gupta, Bishnupriya. 2001. "The International Tea Cartel during the Great Depression, 1929-1933." The Journal of Economic History 61(1):144-159.

Head, Keith, Thierry Mayer and John Ries. 2010. "The erosion of colonial trade linkages after independence." Journal of International Economics 81(1):1-14.

Hillberry, Russell and David Hummels. 2013. Trade Elasticity Parameters for a Computable General Equilibrium Model. In Handbook of Computable General Equilibrium Modeling, ed. B. Dixon Peter and W. Jorgenson Dale. Vol. 1 Amsterdam: Elsevier pp. 1213-1269.

Hlaing, Aye. 1964. "Trends of Economic Growth and Income Distribution in Burma, 1870-1940." Journal of the Burma Research Society XLVII(i):89-148.

Imbs, Jean and Isabelle Mejean. 2017. "Trade Elasticities." Review of International Economics 25(2):383-402.

Indian Tariff Board. 1932. Report of the Indian Tariff Board Regarding the Grant of Protection to the Cotton Textile Industry. Calcutta: Government of India Central Publication Branch.

Irwin, Douglas A. 1998. "The Smoot-Hawley Tariff: A Quantitative Assessment." Review of Economics and Statistics 80(2):326-334.

Irwin, Douglas A. 2012. Trade Policy Disaster : Lessons from the 1930s. Cambridge, Mass.: MIT Press.

Kehoe, Timothy J. and Kim J. Ruhl. 2013. "How Important Is the New Goods Margin in International Trade?" Journal of Political Economy 121(2):358392. 
Kitson, Michael and Solomos Solomou. 1990. Protectionism and Economic Revival : The British Interwar Economy. Cambridge: Cambridge University Press. GB-9000742 Michael Kitson and Solomos Solomou ill. ; 25 cm.

Klasing, Mariko J. and Petros Milionis. 2014. "Quantifying the Evolution of World Trade, 1870-1949." Journal of International Economics 92(1):185-197.

Kumar, Dharma. 1983. The Fiscal System. In The Cambridge Economic History of India: Volume 2: c.1751-c.1970, ed. Dharma Kumar and Meghnad Desai. Cambridge: Cambridge University Press pp. 905-944.

Lai, Huiwen and Daniel Trefler. 2002. The Gains from Trade with Monopolistic Competition: Specification, Estimation, and Mis-Specification. Working Paper 9169 National Bureau of Economic Research.

Madsen, Jakob B. 2001. "Trade Barriers and the Collapse of World Trade during the Great Depression." Southern Economic Journal 67(4):848-868.

McGrattan, Ellen R. and Andrea Waddle. 2020. "The Impact of Brexit on Foreign Investment and Production." American Economic Journal: Macroeconomics 12(1):76-103.

Meyer, F. V. 1948. Britain's colonies in world trade. Oxford University Press: London.

Mitchener, Kris James and Marc Weidenmier. 2008. "Trade and Empire." The Economic Journal 118(533):1805-1834.

Mukherjee, Aditya. 2001. "British Industrial Policy and the Question of Fiscal Autonomy, 1916-1930." Proceedings of the Indian History Congress 62:726755 .

Osamu, Ishii. 2000. Markets and Diplomacy: The Anglo-Japanese Rivalries over Cotton Goods Markets, 1930-36. In The History of Anglo-Japanese Relations, 1600-2000: Volume II: The Political-Diplomatic Dimension, 1931-2000, ed. Ian Nish and Yoichi Kibata. London: Palgrave Macmillan UK pp. 51-77.

Ramana, Duvvuri V. 1969. National Accounts and Input-Output Accounts of India. Bombay, New York: Asia Publishing House.

Rothermund, Dietmar. 1988. An Economic History of India : From PreColonial Times to 1986. London: Croom Helm. 
Rowe, J. W. F. 1965. Primary Commodities in International Trade. Cambridge: Cambridge University Press.

Roy, Tirthankar. 2017. "The Origins of Import Substituting Industrialization in India." Economic History of Developing Regions 32(1):71-95.

Rutherford, Thomas F. 1999. "Applied General Equilibrium Modeling with MPSGE as a GAMS Subsystem: An Overview of the Modeling Framework and Syntax." Computational Economics 14(1-2):1-46.

Sandberg, Lars G. 1974. Lancashire in Decline : A Study in Entrepreneurship, Technology, and International Trade. Columbus: Ohio State University Press.

Santos Silva, J. M. C. and Silvana Tenreyro. 2006. "The Log of Gravity." Review of Economics and Statistics 88(4):641-658.

Sivasubramonian, S. 2000. The National Income of India in the Twentieth Century. Delhi, Oxford: Oxford University Press.

Statistical Office of the Customs and Excise Department (United Kingdom). 1937. Annual Statement of The Trade of the United Kingdom with British Countries and Foreign Countries. 1935 Compared with the Years 1931-1934. Vol. I. London: HMSO.

Statistical Office of the United Nations. 1951. "Standard International Trade Classification." Statistical Papers Series M(10, second edition).

Statistical Office of the United Nations. 1953. "Commodity Indexes for the Standard International Trade Classification, Preliminary Issue." Statistical Papers Series M(10, indexed version).

Steinberg, Joseph B. 2019. "Brexit and the macroeconomic impact of trade policy uncertainty." Journal of International Economics 117:175-195.

Steinberg, Joseph B. 2020. "The macroeconomic impact of NAFTA termination." Canadian Journal of Economics/Revue canadienne d'économique $53(2): 821-865$.

Stubbings, Matthew. 2019. "Free Trade Empire to Commonwealth of Nations: India, Britain and Imperial Preference, 1903-1932." The International History Review 41(2):323-344. 
Suslow, Valerie Y. 2005. "Cartel Contract Duration: Empirical Evidence from Inter-War International Cartels." Industrial and Corporate Change 14(5):705744 .

Tokarick, Stephen. 2014. "A Method for Calculating Export Supply and Import Demand Elasticities." The Journal of International Trade and Economic Development 23(7):1059-1087.

Tomlinson, B. R. 1979. The Political Economy of the Raj, 1914-1947: The Economics of Decolonization in India. London: Macmillan.

Trefler, Daniel. 1993. "Trade Liberalization and the Theory of Endogenous Protection: An Econometric Study of U.S. Import Policy." Journal of Political Economy 101(1):138-160.

U.K. Parliamentary Papers. 1919. "Joint Select Committee on the Government of India Bill, Vol. I. Report and Proceedings of the Committee." House of Commons Papers 4(203).

U.K. Parliamentary Papers. 1922 Sess II. "Report of the Indian Fiscal Commission 1921-22." Command Papers 2(Cmd. 1764).

U.K. Parliamentary Papers. 1931-32. "Imperial Economic Conference at Ottawa 1932. Summary of Proceedings and Copies of Trade Agreements." Command Papers 11(Cmd. 4174).

U.K. Parliamentary Papers. 1933-34. "Japan No. 2 (1934). Convention between His Majesty in Respect of India and the Emperor of Japan Regarding Commercial Relations Between India and Japan with Protocol." Command Papers 27(Cmd. 4460).

U.K. Parliamentary Papers. 1934-35. "Accounts relating to the Trade and Navigation of the United Kingdom in each month during the year 1935. December, 1935." House of Commons Papers 21.

U.K. Parliamentary Papers. 1937-38. "Treaty Series No. 50 (1937). Protocol Regarding Commercial Relations Between India and Japan [with exchange of notes regarding the prolongation of the convention of July 12, 1934]." Command Papers 31(Cmd. 5600).

United States Congress, Senate. 1952. The International Petroleum Cartel. Staff Report to the Federal Trade Commission Submitted to the Subcommittee 
on Monopoly of the Select Committee on Small Business. Washington, DC: Government Printing Office.

US Secretary of Agriculture. 1933. World Trade Barriers in Relation to American Agriculture. Washington D.C.: Government Printing Office.

Wolcott, Susan. 1991. "British Myopia and the Collapse of Indian Textile Demand." Journal of Economic History 51(2):367-384.

Wolf, Nikolaus and Albrecht O. Ritschl. 2011. "Endogeneity of Currency Areas and Trade Blocs: Evidence from a Natural Experiment." Kyklos 64(2):291312 . 


\section{Online-only Appendices}

\section{Appendix 1. Commodity classification}

The data collection process initially involved collecting information on the 202 individual items falling within 35 3- digit SITC categories over the period 1923/24- 1937/38. However, a number of series which existed in the first year of the sample were discontinued or reclassified in subsequent years. Likewise, new categories were created over time, as imports of particular products were reported in a more disaggregated fashion. Consequently, not all series were consistently observed over the entire sample period.

Our aim was to create the most disaggregated dataset possible, given the changing classifications in the data. This required tracking these changing classifications over time, and figuring out the minimum level of aggregation required to produce series for categories of goods that were consistently defined over time. This had to be done manually rather than algorithmically, in the sense that the classifications in every year had to be read by us, and decisions about aggregation made on that basis.

For example, one of our 114 goods is "Refined Sugar", which is a fairly broad category. Imports of different types of refined sugar were reported over the course of the fourteen years in our sample. For example, "Sugar below 23 Dutch Standard but not below 16 Dutch Standard" and "Sugar, 23 Dutch Standard and above" were reported as separate categories during 1930/31- 1937/38 and we would have preferred to work with these as separate categories in our analysis. However, this was not possible since from 1923/24-1929/1930 these two categories were included in a broader category titled, "Sugar, 16 Dutch Standard and above". We therefore had to aggregate the imports of all refined sugar items from each country in each year, creating a new good classification "Refined Sugar". Imports of this expanded category could be measured consistently over time, whereas imports of "Sugar below 23 Dutch Standard but not below 16 Dutch Standard" and "Sugar, 23 Dutch Standard and above" could not.

We went through a similar procedure for each of the 202 individual items

in our sample. For some items no aggregation was necessary as the items were consistently reported across the sample period at the 202- level (for example, "Wool, raw"). For other series the fact that the classification changed regularly meant that the only way to ensure a consistent series was to aggregate a large number of items. For example, the 16 separate items covering machinery 
and millwork (excluding prime movers or electrical machinery) over the sample period, had to be aggregated up to one series "Machinery and Mill-work. Machinery, not being prime movers or electrical machinery" (good 716001 in our dataset). Since we were aggregating import values rather than quantities, there was no problem regarding different units. Finally, to generate a tariff rate for each of our 114 goods we calculated an unweighted average of the tariff rates of each of the constituent series.

Table 2 lists the top 10 goods by import value in 1923/24, 1930/31 and $1937 / 38$. As can be seen the lists are dominated by cotton manufactures and machinery.

Each of our 114 goods g falls into one of the 35 SITC categories s which we started with when constructing the dataset. We are using the original Standard International Trade Classification, based on Statistical Office of the United Nations $(1951 ; 1953)$, since this is more appropriate for this period than more recent revisions. On average there are 3.25 goods per SITC category, but the range is relatively wide (standard deviation of 3.76 goods and a maximum of 13 goods per SITC category). For example, "Iron or steel, Sheets and plates" is included with 12 other goods in SITC 681, "Iron or steel". The good "Grain, wheat" is the only good in SITC 041. Of the 35 3- digit SITC categories in our dataset, 20 contain one good, 9 contain between 2 to 6 goods and 6 contain more than 6 goods. Table 3 lists the top 10 3- digit SITC categories in our sample by import value.

Out of these 34 SITC groups we construct 9 narrow categories which are used when estimating the $\sigma$ 's. 'Grain' includes barley, maize, wheat and rice (SITC categories 041-044); 'Animal' includes butter, eggs and meat (SITC categories 011, 012, 023, and 025); 'Machinery' includes SITC categories 711, 712, 714716, and 721; 'Minerals' includes metals, coal and petroleum (SITC categories 311-313, 681, and 682); 'Textiles' includes both yarn and cloth (SITC codes 651-653); 'Miscellaneous inputs' includes such items as fertilisers, rubber, hides and skins, raw cotton and silk, and hair (SITC codes 211, 231, 261-263, 271, and 561); 'Miscellaneous industry' includes vehicles and rubber manufactures, including tyres (SITC codes 629, 713, and 732); 'Food oils' includes oils and oilseeds of various kinds (SITC codes 221 and 412); and 'Colonial' includes coffee, sugar, tea and tobacco (SITC categories 061, 071, 074, and 121).

The maximum number of goods g per narrow category is 29 (for machinery) while the minimum is 2 for animal (just bacon and hams and butter). Full details of the classification of each item in our sample can be found in Appendix 
Table 2: Top 10 goods by import value, 1923/4-1937-8

\begin{tabular}{|c|c|c|}
\hline Rank & Name of good & $\begin{array}{l}\text { Import } \\
\text { value } \\
(£)\end{array}$ \\
\hline \multicolumn{3}{|c|}{$1923-4$} \\
\hline 1 & $\begin{array}{l}\text { Textiles. Cotton. Manufactures. Piecegoods. Grey } \\
\text { unbleached }\end{array}$ & 230495305 \\
\hline 2 & $\begin{array}{l}\text { Textiles. Cotton. Manufactures. Piecegoods. Total of } \\
\text { White (bleached) }\end{array}$ & 154280628 \\
\hline 3 & $\begin{array}{l}\text { Machinery and Mill-work. Machinery, not being prime } \\
\text { movers or electrical machinery. }\end{array}$ & 136491138 \\
\hline 4 & Refined Sugar & 135495900 \\
\hline 5 & Iron or steel. Sheets and plates & 87694242 \\
\hline 6 & Textiles. Cotton. Manufactures. Piecegoods. Printed & 81006827 \\
\hline 7 & Cotton. Twist and Yarn & 79256805 \\
\hline 8 & Textiles. Cotton. Manufactures. Piecegoods. Dyed Goods & 61138025 \\
\hline 9 & Kerosene & 44163650 \\
\hline 10 & $\begin{array}{l}\text { Textiles. Cotton. Manufactures. Piecegoods. Woven } \\
\text { coloured }\end{array}$ & 34230453 \\
\hline \multicolumn{3}{|c|}{$1930-31$} \\
\hline 1 & Refined Sugar & 95032489 \\
\hline 2 & $\begin{array}{l}\text { Machinery and Mill-work. Machinery, not being prime } \\
\text { movers or electrical machinery. }\end{array}$ & 80233630 \\
\hline 3 & $\begin{array}{l}\text { Textiles. Cotton. Manufactures. Piecegoods. Grey } \\
\text { unbleached }\end{array}$ & 68664068 \\
\hline 4 & $\begin{array}{l}\text { Textiles. Cotton. Manufactures. Piecegoods. Total of } \\
\text { White (bleached) }\end{array}$ & 61996389 \\
\hline 5 & Motor vehicles and parts thereof & 49683956 \\
\hline 6 & Kerosene & 46932916 \\
\hline 7 & Iron or steel. Sheets and plates & 39689845 \\
\hline 8 & Cotton, raw & 33503168 \\
\hline 9 & Cotton. Twist and Yarn & 30836081 \\
\hline 10 & Textiles. Artificial Silk & 30387577 \\
\hline \multicolumn{3}{|c|}{$1937-38$} \\
\hline 1 & $\begin{array}{l}\text { Machinery and Mill-work. Machinery, not being prime } \\
\text { movers or electrical machinery. }\end{array}$ & 123184373 \\
\hline 2 & Cotton. Twist and Yarn & 96073065 \\
\hline 3 & Cotton, raw & 70907830 \\
\hline 4 & Motor vehicles and parts thereof & 61566381 \\
\hline 5 & $\begin{array}{l}\text { Textiles. Cotton. Manufactures. Piecegoods. Total of } \\
\text { White (bleached) }\end{array}$ & 48541354 \\
\hline 6 & Textiles. Cotton. Manufactures. Piecegoods. Printed & 32033391 \\
\hline 7 & Textiles. Cotton. Manufactures. Piecegoods. Dyed Goods & 27978136 \\
\hline 8 & Electrical Machinery & 27954546 \\
\hline 9 & Textiles. Artificial Silk & 23650060 \\
\hline 10 & Artificial Silk Yarn & 22693186 \\
\hline
\end{tabular}


Table 3: Top 10 SITC categories by import value, 1923-4-1937/8

\begin{tabular}{llr}
\hline Rank & SITC & Import value $(£)$ \\
\hline \multicolumn{3}{c}{$1923-4$} \\
\hline 1 & 652 & 568161581 \\
2 & 681 & 177780906 \\
3 & 061 & 151451626 \\
4 & 716 & 139220374 \\
5 & 651 & 98071503 \\
6 & 313 & 84368595 \\
7 & 653 & 56580281 \\
8 & 721 & 43683788 \\
9 & 682 & 41943173 \\
10 & 732 & 27873604 \\
\hline \multicolumn{3}{c}{$1930-31$} \\
\hline 1 & 652 & 200908781 \\
2 & 061 & 108654772 \\
3 & 681 & 96611826 \\
4 & 313 & 90364540 \\
5 & 716 & 82501535 \\
6 & 653 & 59425682 \\
7 & 651 & 52937582 \\
8 & 721 & 50090473 \\
9 & 732 & 49683956 \\
10 & 263 & 33504005 \\
\hline \multicolumn{3}{c}{$1937-38$} \\
\hline 1 & 652 & 138342580 \\
2 & 651 & 137820965 \\
3 & 716 & 126515086 \\
4 & 681 & 75158202 \\
5 & 263 & 70907830 \\
6 & 721 & 68930479 \\
7 & 313 & 62189296 \\
8 & 732 & 61566381 \\
9 & 653 & 50808510 \\
10 & 711 & 25993929 \\
\hline \multicolumn{3}{c}{}
\end{tabular}


Table 1, available at https://cepr.org/research/data-set-items.

Table 4 presents an extract from Appendix Table 1, which lays out the structure of the data as originally collected, and details how it was aggregated. We take the example of the 3-digit SITC category 682, "Copper". In the first column we list the individual items as they were reported in the trade statistics (i.e. at the 202 level of disaggregation), such as "Metals and Ores. Copper. Unwrought. Tiles, ingots, cakes, bricks and slabs". The ID 682-009 is the one used for this item in our original dataset. The second column lists the name of the item as reported in the trade statistics. The third column shows a numerical ID for the good $\mathrm{g}$ to which the item in question belongs, in this instance "Copper. Unwrought" (given in the fourth column). There are 114 of these goods. The fifth column lists the 3 -digit SITC code s to which the item and good in question belong (in this case 682). The seventh column lists the narrow category $\mathrm{h}$ to which the item, good, and SITC code belong (in this case 4, minerals: the narrow categories are listed from 1-9 in the same order as they appear in the regression tables). 
Table 4: Extract from Appendix Table 1

\begin{tabular}{|c|c|c|c|c|c|}
\hline ID & Full Name Item & $\begin{array}{l}\text { Good } \\
\text { Dataset } \\
\text { ID }\end{array}$ & Good & $\begin{array}{l}\text { SITC } \\
3- \\
\text { digit }\end{array}$ & $\begin{array}{l}\text { Narrow } \\
\text { cat- } \\
\text { e- } \\
\text { gory }\end{array}$ \\
\hline $\begin{array}{l}682- \\
001\end{array}$ & $\begin{array}{l}\text { Implements, apparatus and appliances, } \\
\text { and parts thereof. Electrical, including } \\
\text { telegraph and telephone apparatus, not } \\
\text { being machinery. Bare copper wire } \\
\text { (electrolytic), other than telegraph and } \\
\text { telephone wires }\end{array}$ & 682001 & $\begin{array}{l}\text { Bare copper wire } \\
\text { (electrolytic), other } \\
\text { than telegraph and } \\
\text { telephone wires }\end{array}$ & 682 & 4 \\
\hline $\begin{array}{l}682- \\
002\end{array}$ & $\begin{array}{l}\text { Metals and Ores. Brass, bronze, and } \\
\text { similar alloys and manufactures thereof. } \\
\text { Unwrought }\end{array}$ & 682002 & $\begin{array}{l}\text { Brass, bronze and } \\
\text { similar alloys and } \\
\text { manufactures thereof }\end{array}$ & 682 & 4 \\
\hline $\begin{array}{l}682- \\
003\end{array}$ & $\begin{array}{l}\text { Metals and Ores. Brass, bronze, and } \\
\text { similar alloys and manufactures thereof. } \\
\text { Wrought.Mixed or yellow metal for } \\
\text { sheathing }\end{array}$ & 682002 & $\begin{array}{l}\text { Brass, bronze and } \\
\text { similar alloys and } \\
\text { manufactures thereof }\end{array}$ & 682 & 4 \\
\hline $\begin{array}{l}682- \\
004\end{array}$ & $\begin{array}{l}\text { Metals and Ores. Brass, bronze, and } \\
\text { similar alloys and manufactures thereof. } \\
\text { Wrought. Rods }\end{array}$ & 682002 & $\begin{array}{l}\text { Brass, bronze and } \\
\text { similar alloys and } \\
\text { manufactures thereof }\end{array}$ & 682 & 4 \\
\hline $\begin{array}{l}682- \\
005\end{array}$ & $\begin{array}{l}\text { Metals and Ores. Brass, bronze, and } \\
\text { similar alloys and manufactures thereof. } \\
\text { Wrought. Sheets }\end{array}$ & 682002 & $\begin{array}{l}\text { Brass, bronze and } \\
\text { similar alloys and } \\
\text { manufactures thereof }\end{array}$ & 682 & 4 \\
\hline $\begin{array}{l}682- \\
006\end{array}$ & $\begin{array}{l}\text { Metals and Ores. Brass, bronze, and } \\
\text { similar alloys and manufactures thereof. } \\
\text { Wrought. Tubes }\end{array}$ & 682002 & $\begin{array}{l}\text { Brass, bronze and } \\
\text { similar alloys and } \\
\text { manufactures thereof }\end{array}$ & 682 & 4 \\
\hline $\begin{array}{l}682- \\
007\end{array}$ & $\begin{array}{l}\text { Metals and Ores. Brass, bronze, and } \\
\text { similar alloys and manufactures thereof. } \\
\text { Wrought. Wire }\end{array}$ & 682002 & $\begin{array}{l}\text { Brass, bronze and } \\
\text { similar alloys and } \\
\text { manufactures thereof }\end{array}$ & 682 & 4 \\
\hline $\begin{array}{l}682- \\
008\end{array}$ & $\begin{array}{l}\text { Metals and Ores. Brass, bronze, and } \\
\text { similar alloys and manufactures thereof. } \\
\text { Wrought. Other sorts }\end{array}$ & 682002 & $\begin{array}{l}\text { Brass, bronze and } \\
\text { similar alloys and } \\
\text { manufactures thereof }\end{array}$ & 682 & 4 \\
\hline $\begin{array}{l}682- \\
009\end{array}$ & $\begin{array}{l}\text { Metals and Ores. Copper. Unwrought. } \\
\text { Tiles, ingots, cakes, bricks and slabs }\end{array}$ & 682003 & Copper. Unwrought & 682 & 4 \\
\hline $\begin{array}{l}682- \\
010\end{array}$ & $\begin{array}{l}\text { Metals and Ores. Copper. Unwrought. } \\
\text { Other sorts }\end{array}$ & 682003 & Copper. Unwrought & 682 & 4 \\
\hline $\begin{array}{l}682- \\
011\end{array}$ & $\begin{array}{l}\text { Metals and Ores. Copper. Wrought. } \\
\text { Braziers and sheets }\end{array}$ & 682004 & Copper. Wrought & 682 & 4 \\
\hline $\begin{array}{l}682- \\
012\end{array}$ & $\begin{array}{l}\text { Metals and Ores. Copper. Wrought. } \\
\text { Braziers }\end{array}$ & 682004 & Copper. Wrought & 682 & 4 \\
\hline $\begin{array}{l}682- \\
013\end{array}$ & $\begin{array}{l}\text { Metals and Ores. Copper. Wrought. } \\
\text { Rods }\end{array}$ & 682004 & Copper. Wrought & 682 & 4 \\
\hline $\begin{array}{l}682- \\
014\end{array}$ & $\begin{array}{l}\text { Metals and Ores. Copper. Wrought. } \\
\text { Sheets }\end{array}$ & 682004 & Copper. Wrought & 682 & 4 \\
\hline $\begin{array}{l}682- \\
015\end{array}$ & $\begin{array}{l}\text { Metals and Ores. Copper. Wrought. } \\
\text { Tubes }\end{array}$ & 682004 & Copper. Wrought & 682 & 4 \\
\hline $\begin{array}{l}682- \\
016\end{array}$ & $\begin{array}{l}\text { Metals and Ores. Copper. Wrought. } \\
\text { Wire excluding telegraphic and } \\
\text { telephonic wire }\end{array}$ & 642904 & Copper. Wrought & 682 & 4 \\
\hline $\begin{array}{l}682- \\
017\end{array}$ & $\begin{array}{l}\text { Metals and Ores. Copper. Wrought. } \\
\text { Other manufactures }\end{array}$ & 682004 & Copper. Wrought & 682 & 4 \\
\hline
\end{tabular}




\section{Online Appendix 2. List of countries used in the analysis}

Table 5 provides a list of the 42 countries used in our analysis and indicates how they were described in the original sources. In some cases, we had to type

in data for several regions to calculate the data for one country. In the case of Spain, we summed over Canary Isles and Spain; in the case of British Malaya, we summed over the Federated Malay States, British Borneo and the Straits Settlements; and in the case of Dutch East India we summed over Sumatra, Dutch Borneo, and Celebes and Other Islands. 
Table 5: Countries in dataset

\begin{tabular}{|c|c|}
\hline Countries in dataset & As described in original sources \\
\hline Algeria & Algeria \\
\hline \multirow[t]{2}{*}{ Argentina } & Argentine Republic (including Atlantic \\
\hline & Coast of Patagonia) \\
\hline Australia & Australian Commonwealth \\
\hline Austria & Austria \\
\hline Belgium & Belgium \\
\hline Brazil & Brazil \\
\hline British Malaya (all federated and non & Federated Malay States; British Borneo; \\
\hline federated) & Straits Settlements (incl. Labuan) \\
\hline \multicolumn{2}{|l|}{ Jamaica, Trinidad/ Tobago, Others) } \\
\hline Canada & Canada - Atlantic and Pacific Coast \\
\hline Chile (including Pacific Coast of Patagonia) & Chile (including Pacific Coast of Patagonia) \\
\hline China (exclusive of Hong Kong and Macau) & China (exclusive of Hong Kong and Macau) \\
\hline Colombia & Colombia \\
\hline Cuba & Cuba \\
\hline Czechoslovakia & Czechoslovakia \\
\hline Denmark & Denmark \\
\hline \multirow[t]{2}{*}{ Dutch East India } & Java; Sumatra; Celebes and other Islands; \\
\hline & Borneo (Dutch); \\
\hline Dutch West Indies & Dutch West Indies \\
\hline Egypt & Egypt; Anglo-Egyptian Sudan \\
\hline France & France \\
\hline Germany & Germany \\
\hline Hong Kong & Hong Kong \\
\hline Hungary & Hungary \\
\hline Italy & Italy; Fiume \\
\hline Japan & Japan; Formosa \\
\hline Luxemburg & Luxemburg \\
\hline Mexico & Mexico \\
\hline Netherlands & Netherlands \\
\hline \multirow[t]{2}{*}{ New Zealand } & New Zealand (including Nauru and British \\
\hline & Samoa) \\
\hline Norway & Norway \\
\hline Persia & Persia; Henjam Island \\
\hline Poland (including Dantzig) & Poland (including Dantzig) \\
\hline Roumania & Roumania \\
\hline \multirow[t]{3}{*}{ Russia } & Armenia; Russia - Northern; Russia - \\
\hline & Southern; Georgia; Russia - Pacific Ports in \\
\hline & Asia \\
\hline Spain & Spain; Canary Islands \\
\hline Sweden & Sweden \\
\hline Switzerland & Switzerland \\
\hline Turkey, European and Asiatic & Turkey. European and Asiatic \\
\hline Union of South Africa (incl. South West & Cape of Good Hope; Transvaal; Natal; \\
\hline Africa) & 44 4 rotectorate of South-West Africa; \\
\hline United Kingdom & Channel Islands; United Kingdom \\
\hline \multirow[t]{2}{*}{ United States of America } & United States of America - Pacific Coast; \\
\hline & United States of America - Atlantic Coast \\
\hline Venezuela & Venezuela \\
\hline Yugoslavia & Serb-Croat Slovene State (Jugoslavia) \\
\hline
\end{tabular}




\section{Online Appendix 3. Non-tariff barriers to trade and cartels}

Table 6 lists the commodities in our dataset that were affected by the quota on Japanese piece goods that came into effect in 1934. The "quota" dummy variable in the regressions reported in Table 1 takes the value 1 for the goods and years indicated in the table (for Japan only).

Table 6: Non-tariff barriers to trade

\begin{tabular}{llr}
\hline Commodity & Description of commodity & Years \\
\hline 652002 & $\begin{array}{l}\text { Textiles. Cotton. Manufactures. Piecegoods. Grey } \\
\text { unbleached }\end{array}$ & $1934-$ \\
& Textiles. Cotton. Manufactures. Piecegoods. Total of & $1934-$ \\
& White (bleached) & \\
652003 & Textiles. Cotton. Manufactures. Piecegoods. Printed & $1934-$ \\
652005 & Textiles. Cotton. Manufactures. Piecegoods. Dyed Goods & $1934-$ \\
652006 & Textiles. Cotton. Manufactures. Piecegoods. Woven & $1934-$ \\
& coloured & $1937-$ \\
652007 & Textiles. Cotton. Manufactures. Piecegoods. Fents of all & \\
\hline & descriptions | & \\
Source: U.K. Parliamentary Papers (1933-34, pp. 471-478, especially Protocol, Article 7, p. \\
477); U.K. Parliamentary Papers (1937-38, pp. 397-403, especially Protocol, Article 8, p. \\
$\begin{array}{ll}\text { 401). } \\
\text { Note: good 652001 is cotton canvas, and is not mentioned in the aforementioned sources. }\end{array}$
\end{tabular}

Indian industries were involved in a number of cartels which may have influenced trade flows during this period. Indian producers joined an international tea agreement in 1930. This was not renewed in 1931 and 1932, but from 1933 up to the Second World War it attempted to freeze the market share of the three participating countries, India, Ceylon and the Dutch East Indies (Gupta, 2001; Suslow, 2005). The tea agreements seem to have been moderately successful in 1930 in slowing the decline in tea prices, and to have stabilized and reflated tea prices after 1933, a period when prices for similar goods such as cocoa and coffee continued to fall (Gupta, 2001; Rowe, 1965, pp. 90, 148-51). Since the agreement mostly affected Indian producers and exporters of tea, its effect on tea imports remains unclear in the literature. The International Rubber Regulation Agreement of 1934 only came into force as international recovery after the Great Depression was already underway, and India was a fairly minor player in this market in comparison to Malaya, the Dutch East Indies, Ceylon and Indochina (Rowe, 1965, pp. 90,152-4), so the consequences of the export quotas 
agreed upon by the contracting parties on the structure of Indian imports remains unclear as well. India was also probably affected by the Achnacarry and subsequent agreements in the petroleum industry (United States Congress, Senate, 1952), as well as by the Chadbourne sugar agreement, which India joined together with the UK in late 1937 (Dye and Sicotte, 2006).

Table 7 below provides data on how these cartels were coded in our dataset. International producer cartels in which British India was a member were coded from Suslow (2005, Appendix 1). This was supplemented by information on primary goods, and especially international sugar cartels, in Dye and Sicotte (2006), US Secretary of Agriculture (1933), and Rowe (1965), and by information on the Achnacarry and subsequent agreements in the petroleum industry, in United States Congress, Senate (1952). We only include formal cartel agreements concluded by British India domestic producers, trade organizations, or the government. Cartels have to be in force at least 6 month in the corresponding year to be coded as dummy=1. Only cartel members included in our country sample are mentioned in the table. 


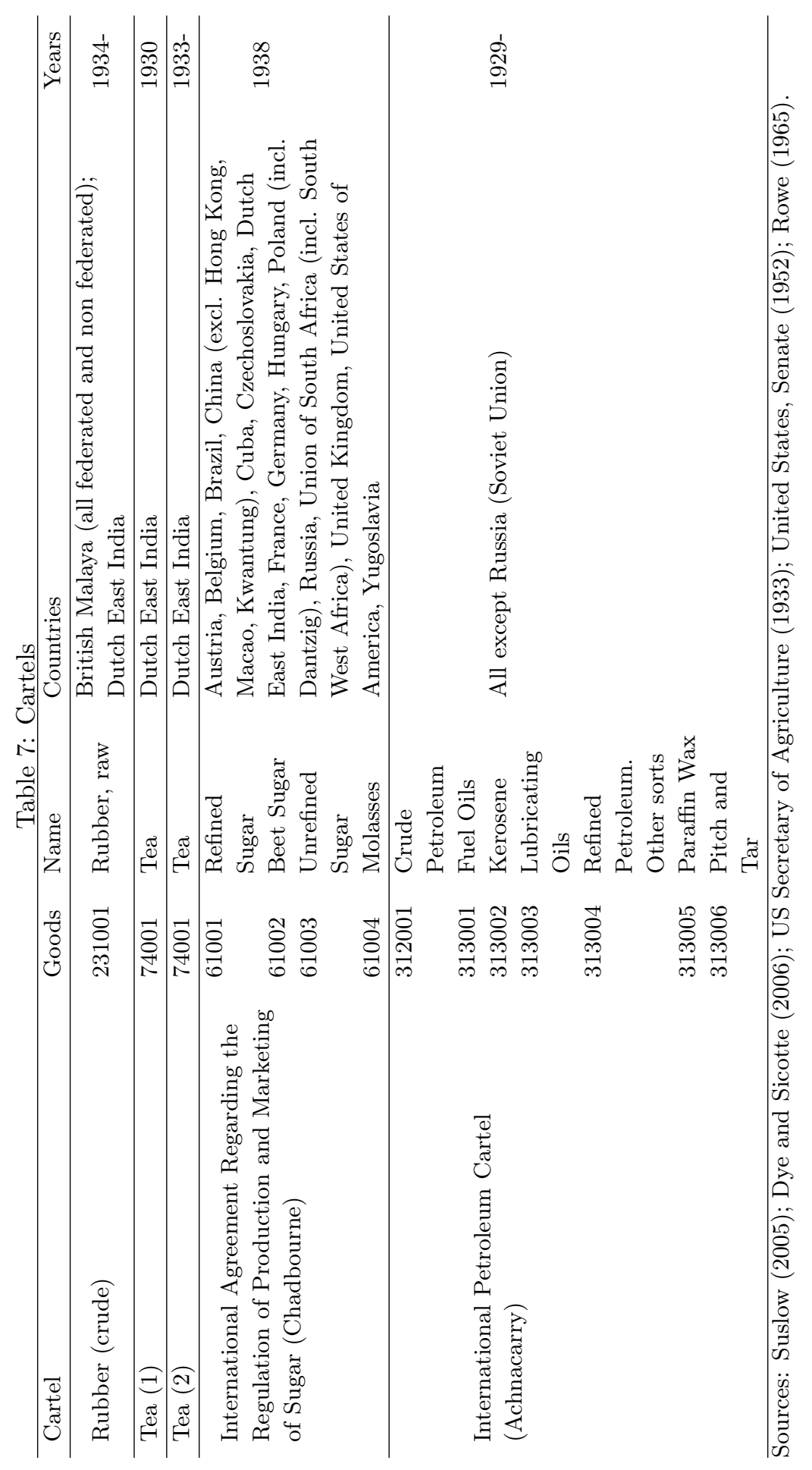




\section{Online Appendix 4. Robustness}

\section{Alternative estimates of the $\sigma_{g}$ 's}

As a robustness exercise we let the $\sigma_{g}$ 's vary across the nine categories $h$ mentioned in the text. With fewer degrees of freedom available to us, we were unable to include all the fixed effects of our main specification, which is why we prefer the specification in the text. As in column (1) of Table 1 we include goodyear $\left(d_{g t}\right)$ and good-country $\left(d_{g c}\right)$ fixed effects. However, we could not include country-time fixed effects; instead we controlled for country GDP $G D P_{c t}$ and the bilateral exchange rate $E_{c t}$, and also include country-specific time trends $d_{c} \times$ trend. Nominal exchange rates were calculated as annual averages of closing daily exchange rates and were taken from Global Financial Data. ${ }^{42}$ Nominal GDP was taken from Klasing and Milionis (2014), adjusted for interwar borders using the adjustment coefficients from Broadberry and Klein (2012). Our estimating equation was therefore:

$$
\begin{gathered}
\ln \left(V_{g c t}^{W}\right)=\alpha_{h} \ln \left(G D P_{c t}\right)+\beta_{h} \ln \left(E_{c t}\right)-\sigma_{h} \ln \left(1+t_{g c t}\right) \\
-\sigma_{h} \sum_{i=1}^{n} \ln \left(b_{i}\right) \delta_{i g c t}+d_{g t}+d_{g c}+d_{c} \times \text { trend }+u_{g c t}
\end{gathered}
$$

where $b_{i}-1$ is the ad valorem equivalent of facing non-tariff barrier $i$; and $\delta_{i g c t}$ is an indicator variable taking the value 1 if imports of good $g$ from country $c$ face barrier $i$ in year $t$, and zero otherwise. As before, the key non-tariff barrier we are concerned with is the quota on Japanese cotton piece goods, and as before we also control for cartels. In addition, we control for the League of Nations trade sanctions against Italy which operated from November 1935 to June 1936 (we let a dummy variable be equal to one in 1936 for all imports coming from Italy in that year), as well as the boycott of UK cotton cloth which began in 1930. We allow the latter to have a differential impact in 1930 and subsequent years, including two variables in the regression for this purpose.

The key elasticities are the coefficients on the tariff variable, which are our estimates of the $\sigma_{h}$ 's. We were unable to estimate these for three commodity categories (grain, animal products, and miscellaneous inputs) for the simple reason that there was no between-country variation in tariff rates for those

\footnotetext{
${ }^{42}$ https://www.globalfinancialdata.com/index.html, accessed June 2013.
} 


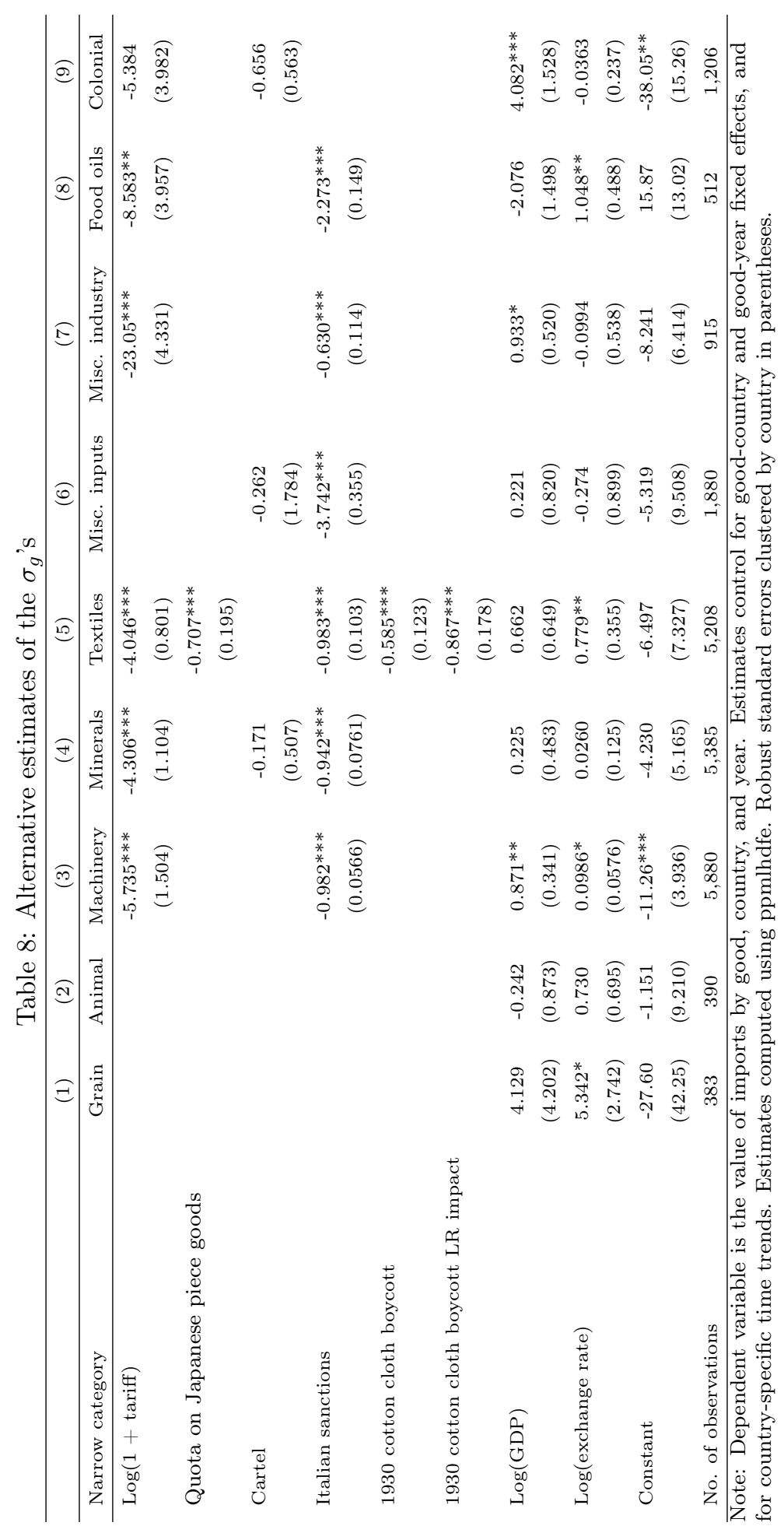


products (i.e. there was no discrimination involving these goods). For the other six categories the elasticities range from a minimum of 4.0 (textiles) to a maximum of 23.1 (miscellaneous industry). The coefficients on the quota and tariff variables in column (5) jointly imply that the quota on Japanese piece goods was equivalent to a $19.1 \%$ ad valorem tariff. ${ }^{43}$

We re-ran our simulations using four sets of elasticities. These are: the benchmark elasticities used in the body of the paper; the benchmark elasticities, but with the value of $\gamma$ lowered from its benchmark value of 1 to 0.5 ; the benchmark elasticities, but with $\gamma$ raised to 2 ; and the sectoral elasticities in Table 8 (setting $\gamma=1$ ). For the three commodity categories (grain, animal products, and miscellaneous inputs) for which we could not estimate $\sigma_{h}$ we used the estimates provided in de Bromhead et al. (2019).

Figure 11 shows the estimated impact of post-1923 protection on aggregate trade flows (India's total imports, and the UK's and Japan's aggregate exports to that country) under each of these four elasticity scenarios. As can be seen, our results are not particularly sensitive to the elasticities used, except insofar as total UK exports are concerned. The estimated impact of Indian protection on UK exports is much higher when $\gamma=2$, and lower when $\gamma=0.5$. Figure 12 performs the same exercise for UK and Japanese exports of cotton cloth to India. Once again the Japanese results are less sensitive to the elasticities used, and the UK results more so. In both cases, however, the estimated impact of protection on trade flows is large, and our qualitative results survive.

\footnotetext{
${ }^{43}$ Similarly the boycott was equivalent to a $15.6 \%$ tariff on British cloth in 1930 , and a $23.9 \%$ tariff in subsequent years.
} 
Figure 11: Impact of protection on aggregate trade with different elasticities
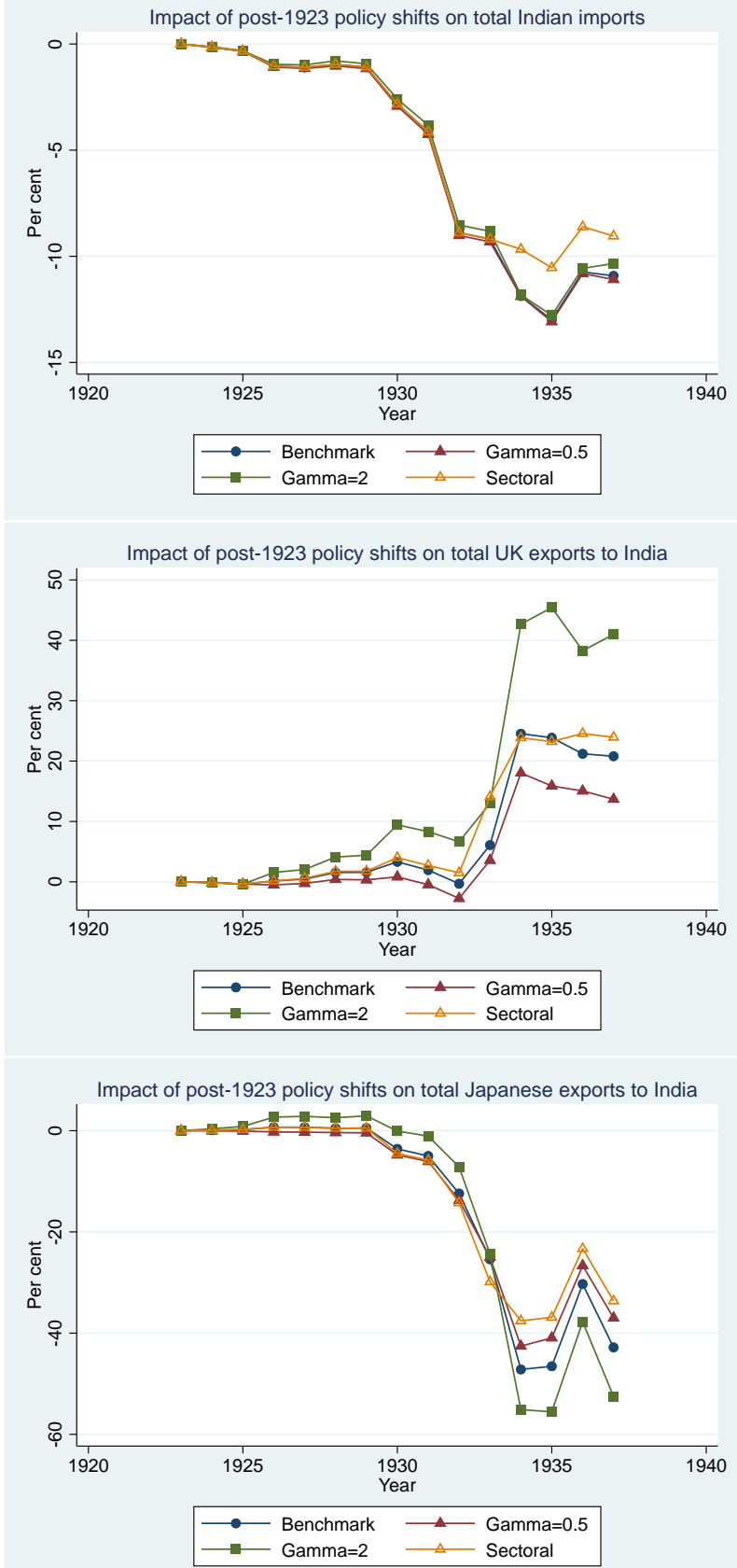

Note: this graph plots the percentage difference between the stated trade flows actually observed in each year, and the counterfactual level that would have obtained had tariffs and quotas remained at their 1923 levels throughout. It does so for different elasticity scenarios described in the text. 
Figure 12: Impact of protection on cotton cloth exports to India with different elasticities
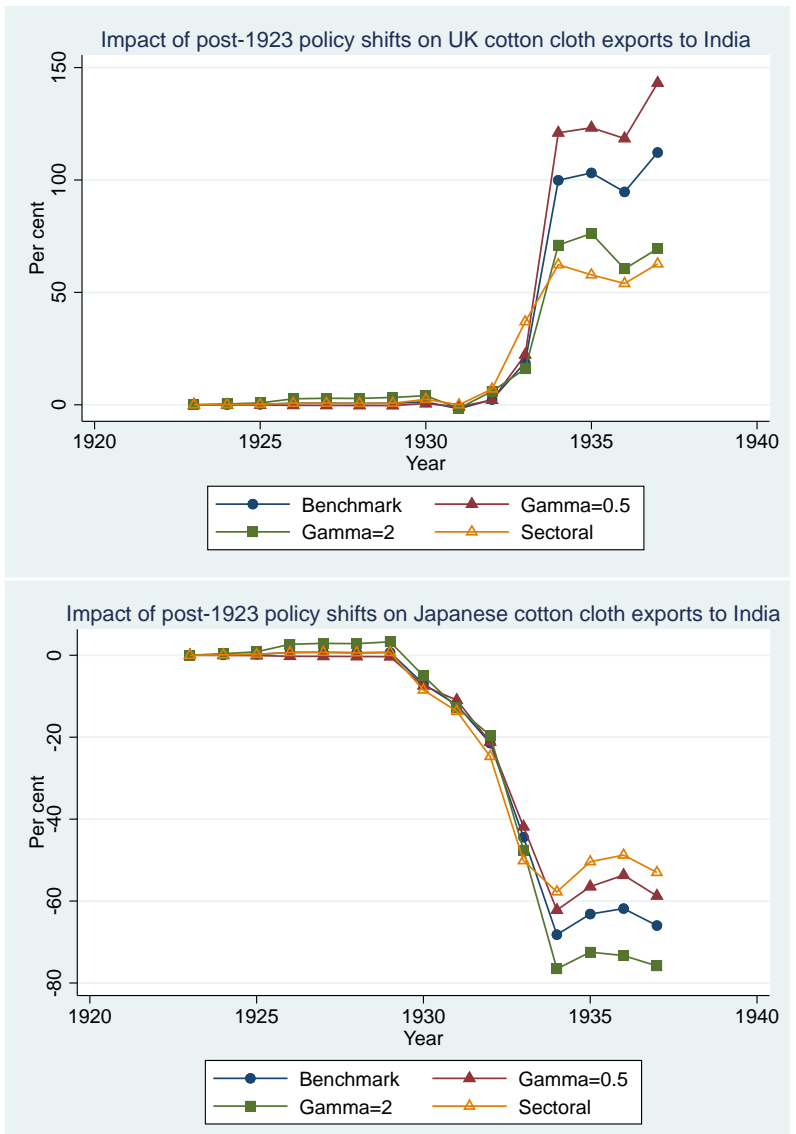

Note: this graph plots the percentage difference between the stated trade flows actually observed in each year, and the counterfactual level that would have obtained had tariffs and quotas remained at their 1923 levels throughout. It does so for different elasticity scenarios described in the text. 